\title{
A Systematic Literature Review on IT Outsourcing Decision and Future Research Directions
}

\author{
Payam Hanafizadeh, Chalmers University of Technology, Gothenburg, Sweden \\ https://orcid.org/0000-0002-5233-987X \\ Ahad Zareravasan, Masaryk University, Brno, Czech Republic \\ (iD) https://orcid.org/0000-0002-9477-0676
}

\begin{abstract}
During the recent decades, some academic research on the subject of information technology outsourcing (ITO) decision has appeared in different outlets, which may impede the use of such resources and as a result, repetition of research by various researchers is very likely. The purpose of this paper is then to conduct a systematic literature review (SLR) pertaining to research on ITO decision. Then, this review intends to 1) classify ITO decision literature, 2) provide a list of factors affecting ITO decision, and 3) identify ITO strategies. To this end, 91 ITO articles published between 2000 and 2018 in 51 unique journals were reviewed. The results yielded three kinds of descriptive, relational, and comparative ITO decision studies. The determinants of ITO decisions are classified into technological, organizational, environmental and user adoption factors. Furthermore, the trend of studied ITO strategies in the reviewed literature is analyzed, and future sourcing varietals are proposed. Finally, some insights and future research directions are proposed based on the review results.
\end{abstract}

\section{KEYWORDS}

IT Outsourcing Decision, IT Outsourcing Strategies, Systematic Literature Review, Technology Organization and Environment (TOE) Model

\section{INTRODUCTION}

Information technology outsourcing (ITO) is defined as handing over to a third party, management of IT assets, resources, and activities for a required result. Examples of outsourced IT activities include Information systems (IS)/ Applications development, operations, and maintenance, network and telecommunications management, help desk and end-user support, and systems planning and management (Rajaeian, Cater-Steel, \& Lane, 2017). In this paper, we use ITO as a generic term that covers various ways to obtain IT resources/ services from external organizations (through, e.g., offshore outsourcing, IS development outsourcing, Business Process Outsourcing (BPO), and Cloud computing (CC)).

\section{DOI: 10.4018/JGIM.2020040108}

This article, originally published under IGI Global's copyright on December 20, 2019 will proceed with publication as an Open Access article starting on January 11, 2021 in the gold Open Access journal, Journal of Global Information Management (converted to gold Open Access January 1, 2021), and will be distributed under the terms of the Creative Commons Attribution License (http://creativecommons.org/ licenses/by/4.0/) which permits unrestricted use, distribution, and production in any medium, provided the author of the original work and original publication source are properly credited. 
One of the main recent ITO research streams relates to ITO decision subject. ITO decision can be viewed from vendor and client perspectives (Moon, Yao, \& Jiang, 2011). ITO decision from vendor perspective includes but not limited to risks in provided services, contract conflicts, pricing mechanisms, and so on (Palvia \& Palvia, 2017) which is not of concern in this research. ITO research on client aspect - the focus of this study - can be categorized into five distinct groups, each of which tries to answer one of the questions: why, what, where, when, how to outsource. The category of "why" tries to mainly answer "why" firms outsource IT or "what" their related motives and drawbacks are. The question of "what" to outsource investigates to what degree firms can outsource their strategic or core competence IT services to external vendors and which sourcing strategy best suits a firm. The main issue concerned with making the location decision for outsourced activities is "where" to outsource. Also, the correct timing of outsourcing decisions is categorized under "when" question. Finally, to understand the outsourcing phenomenon and the strategic changes in the companies comprehensively, one also has to be aware of "how" outsourcing is done, that is, the process of outsourcing (Hätönen $\&$ Eriksson, 2009). To answer these questions, scholars have investigated different aspects of ITO decision. However, to the best of authors' knowledge, there is no classification scheme for ITO decision extant literature. To address this gap, we ask the first research question:

RQ1: How extant ITO decision literature can be classified?

ITO decision making is a very complicated task with a wide range of factors impacting upon decision outcome (Zare Ravasan, Hanafizadeh, Olfat, \& Taghavifard, 2017). Studies implied that to make the ITO decision adequately, the chief information officer (CIO) must spend approximately $80 \%$ of his time, for three to six months (D.-H. Yang, Kim, Nam, \& Min, 2007). Therefore, identifying factors affecting proper ITO decisions could lead to more managed IT outsourced services and processes. Scholars to address this practitioner concern, have investigated a varied set of factors influencing ITO decisions considering different theoretical bases such as transaction cost economics (TCE), resource-based view (RBV), technology acceptance model (TAM), and so on. By taking so many theories into account, researchers have tested a large number of relationships between independent and dependent variables. Due to its diversity, findings from the overall body of literature on ITO decision have been difficult to summarize, analyze, and evaluate the contradicting results of different research. For instance, Hanafizadeh and Zare Ravasan (2018a) reported a positive relationship between asset specificity and ITO decision while Poppo and Zenger (2002) suggested a negative relationship. To address this research problem, we proposed our second research question as follows:

RQ2: What are the factors affecting ITO decision?

Furthermore, scholars investigated determinants of different types of ITO like offshore/ nearshore outsourcing, rural outsourcing, IS development outsourcing, Business Process Outsourcing (BPO), Cloud computing (CC), Software as a Service (SaaS), platform as a Service (PaaS), and Infrastructure as a Service (IaaS), and so on. However, there is no assessment of this body of literature to provide a trend analysis of ITO strategies/ types covered in the prior research. Then, to fill this research gap, we propose third research question as follows:

RQ3: What are the ITO strategies trend in extant ITO research?

Besides the first three questions, we also present additional findings in a distinct section that are interesting and provides valuable insights with a focus to answer following research question.

RQ4: What are promising areas for future research? 
To address these research questions, a Systematic Literature Review (SLR) approach was adopted in this study. SLR is one of the most effective ways of summarizing extant empirical literature and thereby formulating conclusions by employing different theoretical bases, research methods, sampling, etc. The need for and importance of literature reviews in the IT discipline has been recently highlighted because such papers provide valuable insights on prior research and provide a direction for future studies and can be used to raise academics as well as practitioners' awareness of extant research (Rajaeian et al., 2017). With this in mind, this study attempts to provide an SLR to answer aforementioned research questions.

\section{PRIOR ITO LITERATURE REVIEWS}

In this section, a brief review of prior major ITO literature reviews is proposed to illustrate this review contribution. Among the first literature review studies, we can refer to Dibbern et al. (2004) in which 84 publications between 1992 and 2000 were reviewed. They examined the research objectives, methods used and theoretical foundations of the papers in their review. Moreover, they organized ITO papers based on ITO decision (why, what, which) and implementation (how, outcome) phases. Fjermestad and Saitta (Fjermestad \& Saitta, 2005) reviewed 29 articles on ITO published between 1981 and 2004. They provided an eight-component critical factors framework (strategic alignment, contracts, technology, culture, strategic partnership, management support, governance committees, and economics).

Mahnke et al. (2005) by reviewing 19 ITO articles published between 1995 and 2002 that used Transaction cost economics (TCE), Resource-based View (RBV) and the Relational View, concluded that the independent variables from current theoretical explanations are too limited. Furthermore, they proposed a process model of ITO based on these theories. Gonzalez et al. (2006) analyzed 131 articles on IS outsourcing published between 1988 and 2005. They examined the literature based on research approach and research perspective (i.e., client, supplier, or both), and finally, 24 most prolific ITO researchers are introduced. Lacity et al. (2009) focused a review of the ITO literature on proposing practical implications for firms. They analyzed 191 ITO articles published between 1990 and 2008 around six topics: (1) determinants of IT, (2) ITO strategy, (3) ITO risks, (4) determinants of IT, (5) client and supplier, and (6) sourcing varietals.

Alsudairi and Dwivedi (2010) categorized 315 outsourcing articles published from 1992 to 2008 by the frequency of articles published by subject area, journal, author, university affiliation, and citation counts and provided insights based on analyzed data. Lacity et al. (2010) reviewed 164 published empirical papers between 1992 and 2010 and provided a model of ITO decisions including independent variables associated with motives to outsource, transaction attributes, client firm characteristics, and influence sources. A year later, by extracting 87 BPO articles published between 1996 and 2011, Lacity et al. (2011) developed two models of BPO: one model addresses BPO decisions and another for BPO outcomes. The model of BPO decisions includes independent variables associated with motives to outsource, transaction attributes, and client firm characteristics. The model of BPO outcomes includes independent variables associated with contractual and relational governance, country characteristics, and client and supplier capabilities.

Liang et al. (2016) employed the main path analysis to map the entire field of ITO literature published from 1992 to 2013 and identified 12 main research streams: motivations for ITO, ITO decisions, ITO risks, transaction cost economics, client-vendor relationship, vendor's perspective, psychological and formal contracts, Application Service Provider (ASP), BPO, offshore outsourcing, open-sourcing, and multi-sourcing. They provided series of future research paths. In a recent work, Schneider and Sunyaev (2016) reviewed the CC and ITO literature published before April 2014 and coded the determinant factors that influence sourcing decisions. They showed that most determinant factors of sourcing decisions in the ITO context remain valid for the CC context. However, the 
findings for some factors (i.e., asset specificity, client firm IT capabilities, client firm size, institutional influences, and uncertainty) are inconclusive for the CC and ITO contexts.

Lacity et al. (2016) extended the time frame of their previous review (i.e., Lacity et al. (2010), Lacity et al. (2011)) by including more recent publications from 2010 to 2014, to investigate the most current research findings on business services (i.e., ITO and BPO), and to compare the results with the prior reviews. They reported more in-depth exploration of the direct effects of transaction attributes, sourcing motivations, client and provider capabilities, and governance on sourcing decisions and outcomes. They have also studied a broader variety of sourcing decisions, including shared services, captive centers, rural sourcing, and back-sourcing. Most recently, Rajaeian et al. (2017) suggested a range of Multiple Criteria Decision Making (MCDM), optimization and simulation methods to support different ITO decisions. Also, they raised concerns about the limited use of reference design theories, and the lack of validation and naturalistic evaluation of the decision support artifacts reported in ITO decision support literature.

In this section, we compare our findings with prior ITO literature reviews to highlight our contributions. We examined previous ITO literature reviews as above. Some of these reviews exhibit substantial differences in research focus with the current review. For example, Lacity et al. (2011) reviewed studies with a focus on the BPO field. We mainly focus on empirical findings from the research, not on the authors or the publications of ITO research which was followed by Gonzalez et al. (2006) and by Alsudairi and Dwivedi (2010). The target audience of this review is academics, not practitioners, as contrasted with Lacity et al. (2009) and Fjermestad and Saitta (2005).

Furthermore, similar to Dibbern et al. (2004) and Mahnke et al. (2005), to answer the $R Q 1$, this review provides an analysis of theoretical foundations applied in previous research and categorizes ITO literature in three descriptive, relational, and comparative groups. Identifying frequently applied theoretical foundations in ITO research could help academics to find out which areas are matured and where more explorations are required.

The focus of this review in $R Q 2$ is on the findings at the level of dependent and independent variables and the relationships between them in the specific aspect of the ITO process; i.e., ITO decision from the client perspective which shares some similar findings with Lacity et al. (2016), and Schneider and Sunyaev (2016) reviews. ITO benefits, risks, costs, security issues are among the repeated factors in all models. However, we proposed our model based on TOE framework by including a new category (i.e., user factors) to incorporate a set of factors influence ITO decisions from the perspectives of user community (here, stakeholders involved or interested in ITO process and outcomes such as top-level managers, middle level managers, IT managers, CIOs, and sourcing managers) which can be considered the unique finding of our model. Providing the factors under TOE categories adds value to academic community, since a significant part of recent publications were based on TOE framework (e.g., Gu, Cao, \& Duan, 2012; Hanafizadeh \& Zare Ravasan, 2017). The proposed model in this review (see Figure 3) can help academics to find out what major determinants of ITO decisions are consistently reported in previous research and what factors need more investigations to fill the research gap. Moreover, this review to answer RQ3, provides a trend analysis of studied ITO strategies (see Figure 4). Besides, this review, to answer RQ4, proposes future research stream in new sourcing varietal (e.g., open-sourcing, multi-sourcing, micro-sourcing, and crowdsourcing). A summary of the ITO literature reviews is provided in Table 1.

\section{SYSTEMATIC LITERATURE REVIEW PLANNING}

This review aims to examine the ITO decision literature thoroughly. The study was carried out by the two authors in student and supervisor role. In case of conflicts, the decision was taken by the supervisor to resolve it. This research follows the SLR method proposed by Bano and Zowghi (2014) which is composed of three steps of planning, execution and reporting results. During the planning phase, we followed a formal protocol for conducting SLR. The protocol contained the details of our 
Table 1. ITO literature reviews

\begin{tabular}{|c|c|c|c|}
\hline Citation & $\begin{array}{l}\text { Review } \\
\text { Period }\end{array}$ & $\begin{array}{l}\text { Sample } \\
\text { Size }\end{array}$ & Results \\
\hline Dibbern et al. (2004) & $\begin{array}{l}1992- \\
2000\end{array}$ & $\begin{array}{l}84 \text { ITO } \\
\text { papers }\end{array}$ & $\begin{array}{l}\text { The authors examined the research objectives, methods used and } \\
\text { theoretical foundations of the papers }\end{array}$ \\
\hline $\begin{array}{l}\text { Fjermestad and } \\
\text { Saitta (Fjermestad \& } \\
\text { Saitta, 2005) }\end{array}$ & $\begin{array}{l}1981- \\
2004\end{array}$ & $\begin{array}{l}29 \text { ITO } \\
\text { papers }\end{array}$ & $\begin{array}{l}\text { The authors provided an eight-component critical factors framework } \\
\text { (strategic alignment, contracts, technology, culture, strategic } \\
\text { partnership, management support, governance committees, and } \\
\text { economics). }\end{array}$ \\
\hline Mahnke et al. (2005) & $\begin{array}{l}1995- \\
2002\end{array}$ & $\begin{array}{l}19 \text { ITO } \\
\text { papers }\end{array}$ & $\begin{array}{l}\text { The authors proposed a process model of ITO based on TCE, RBV } \\
\text { and Relational View theories }\end{array}$ \\
\hline $\begin{array}{l}\text { Gonzalez et al. } \\
(2006)\end{array}$ & $\begin{array}{l}1988- \\
2005\end{array}$ & $\begin{array}{l}131 \text { ITO } \\
\text { papers }\end{array}$ & $\begin{array}{l}\text { The authors analyzed the literature, and finally, } 24 \text { most prolific ITO } \\
\text { researchers are introduced. }\end{array}$ \\
\hline Lacity et al. (2009) & $\begin{array}{l}1990- \\
2008\end{array}$ & $\begin{array}{l}191 \text { ITO } \\
\text { papers }\end{array}$ & $\begin{array}{l}\text { The authors organized the literature that answered six practitioner } \\
\text { questions: (1) determinants of IT, (2) ITO strategy, (3) ITO risks, (4) } \\
\text { determinants of IT, (5) client and supplier, and (6) sourcing varietals }\end{array}$ \\
\hline $\begin{array}{l}\text { Alsudairi and } \\
\text { Dwivedi (2010) }\end{array}$ & $\begin{array}{l}1992- \\
2008\end{array}$ & $\begin{array}{l}315 \text { ITO } \\
\text { papers }\end{array}$ & $\begin{array}{l}\text { The authors categorized the literature by the frequency of articles } \\
\text { published by subject area, journal, author, university affiliation, and } \\
\text { citation counts }\end{array}$ \\
\hline Lacity et al. (2010) & $\begin{array}{l}1992- \\
2010\end{array}$ & $\begin{array}{l}164 \text { ITO } \\
\text { papers }\end{array}$ & $\begin{array}{l}\text { The authors coded the relationships between ITO decision and } \\
\text { related determinants. }\end{array}$ \\
\hline Lacity et al. (2011) & $\begin{array}{l}1996- \\
2011\end{array}$ & $\begin{array}{l}87 \mathrm{BPO} \\
\text { papers }\end{array}$ & $\begin{array}{l}\text { The authors developed two models of BPO: one model addresses } \\
\text { BPO decisions and another for BPO outcomes }\end{array}$ \\
\hline Liang et al. (2016) & $\begin{array}{l}1992- \\
2013\end{array}$ & $\begin{array}{l}798 \text { ITO } \\
\text { papers }\end{array}$ & $\begin{array}{l}\text { The authors identified } 12 \text { main research streams: motivations for } \\
\text { ITO, ITO decisions, ITO risks, transaction cost economics, client- } \\
\text { vendor relationship, vendor's perspective, psychological and formal } \\
\text { contracts, ASP, BPO, offshore outsourcing, open-sourcing, and } \\
\text { multi-sourcing. }\end{array}$ \\
\hline $\begin{array}{l}\text { Schneider and } \\
\text { Sunyaev (2016) }\end{array}$ & $\begin{array}{l}1992- \\
2014\end{array}$ & $\begin{array}{l}88 \mathrm{CC} \\
\text { and ITO } \\
\text { papers }\end{array}$ & $\begin{array}{l}\text { The authors showed that most determinant factors of sourcing } \\
\text { decisions in the ITO context remain valid for the CC context }\end{array}$ \\
\hline Lacity et al. (2016) & $\begin{array}{l}1992- \\
2014\end{array}$ & $\begin{array}{l}174 \text { ITO } \\
\text { papers }\end{array}$ & $\begin{array}{l}\text { The authors by extending the time frame of their previous review } \\
\text { (i.e., Lacity et al. (2010), Lacity et al. (2011)), investigated the most } \\
\text { current research findings on business services (i.e., ITO and BPO), } \\
\text { and compared the results with the prior reviews }\end{array}$ \\
\hline $\begin{array}{l}\text { Rajaeian et al. } \\
(2017)\end{array}$ & $\begin{array}{l}1995- \\
2016\end{array}$ & $\begin{array}{l}133 \mathrm{CC} \\
\text { and ITO } \\
\text { papers }\end{array}$ & $\begin{array}{l}\text { The authors suggested a range of MCDM, optimization and } \\
\text { simulation methods to support different ITO decisions }\end{array}$ \\
\hline This review & $\begin{array}{l}2000- \\
2018\end{array}$ & $\begin{array}{l}91 \text { ITO } \\
\text { papers }\end{array}$ & $\begin{array}{l}\text { This review intends to } 1 \text { ) classify ITO decision literature, 2) } \\
\text { provide a list of factors affecting ITO decision, and 3) identify ITO } \\
\text { strategies. }\end{array}$ \\
\hline
\end{tabular}

primary and secondary search strategy, papers inclusion/exclusion criteria in the review, quality assessment criteria, data extraction strategy, and data synthesis. Then, the steps proposed in the planning stage is conducted in the execution phase. Finally, findings are provided to answer four proposed research questions.

\section{Primary Search Strategy}

The concept of outsourcing can be understood as a combination of three fields: 1) strategic management, 2) international business, and 3) supply chain management (SCM) (Hätönen \& Eriksson, 
2009). In the ITO context, the field of IT can also be included. Accordingly, this study reviewed the literature on ITO decision in databases related to these four fields (i.e., 1) strategic management, 2) international business, 3) SCM, and 4) IT), including: ScienceDirect, Emerald Fulltext, Springer, Infor-Sci IGI Global, Taylor \& Francis, EBSCOhost, and Ingenta Journals. The search engines Google Scholar and Scopus were also used to ensure coverage of publications in other databases.

The keywords IT/IS outsourcing/ sourcing, Software as a Service (SaaS), Platform as a Service (PaaS), Infrastructure as a Service (IaaS), Application Service Provider (ASP), Business Process Outsourcing (BPO), offshore outsourcing, cloud computing (CC), grid computing, AND decision/ adoption/ acceptance, degree of outsourcing, were used to search the titles and abstracts of the papers. The publications between 2000 and 2018 were included in the review for two reasons 1) considering the most recent literature, and 2) publications before 2000 had already been taken into account in previous review studies (Dibbern et al., 2004; Lacity, Willcocks, \& Khan, 2011).

\section{Study Selection Criteria}

Different types of peer-reviewed journal publications, with available English full-text versions, were all considered for the review purpose. Conference papers, master's theses, doctoral dissertations, textbooks, chapter books, and working papers were excluded because academics and practitioners use journals to disseminate new findings. Finally, the papers yielded by the step above were evaluated through considering their abstracts to exclude the studies that did not belong to the domain of ITO decision.

\section{Secondary Search Strategy}

To ensure that we did not miss any of the relevant studies, we devised a secondary search strategy by scanning and reviewing all the references of the included studies. All the eligible citations were surveyed with the inclusion/exclusion criteria described in the previous step. To further ensure that we did not miss any important and relevant papers, in the final step, we selected following literature reviews which are highly cited and published in top-ranked journals to screen their citations for discovering any missed publication:

1. Lacity, M. C., Khan, S. a., \& Willcocks, L. P. (2009). A review of the IT outsourcing literature: Insights for practice. The Journal of Strategic Information Systems, 18(3), 130-146;

2. Lacity, M. C., Khan, S., Yan, A., \& Willcocks, L. P. (2010). A review of the IT outsourcing empirical literature and future research directions. Journal of Information Technology, 25(4), 395-433;

3. Lacity, M. C., Solomon, S., Yan, A., \& Willcocks, L. P. (2011). Business process outsourcing studies: a critical review and research directions. Journal of Information Technology, 26(4), 221-258;

4. Lacity, M. C., Willcocks, L. P., \& Khan, S. (2011). Beyond Transaction Cost Economics: Towards an endogenous theory of Information Technology Outsourcing. The Journal of Strategic Information Systems, 20(2), 139-157;

5. Liang, H., Wang, J. J., Xue, Y., \& Cui, X. (2016). IT outsourcing research from 1992 to 2013: A literature review based on main path analysis. Information and Management, 53(2), 227-251;

6. Schneider, S., \& Sunyaev, A. (2016). Determinant factors of cloud-sourcing decisions: Reflecting on the IT outsourcing literature in the era of cloud computing. Journal of Information Technology, 31(1), 1-31;

7. Lacity, M., Khan, S. A., \& Yan, A. (2016). Review of the empirical business services sourcing literature: an update and future directions. Journal of Information Technology, 31 (3), 269-328;

8. Rajaeian, M.M., Cater-Steel, A., \& Lane, M. (2017). A systematic literature review and critical assessment of model-driven decision support for IT outsourcing. Decision Support Systems. $102,42-56$. 


\section{Data Extraction}

We extracted three types of data: Publication details (e.g., publication date, journal name, country), context description (research method, sample, ITO strategy, theoretical base), and findings (research category, factors affecting ITO decision, outsourcing strategy).

\section{Data Synthesis and Analysis}

To respond to $R Q 1$, identified ITO decision published papers were classified into three groups including descriptive, relational, and comparative as illustrated in Figure 1 that will be discussed more in section "ITO DECISION LITERATURE CLASSIFICATION".

To answer $R Q 2$, we needed to identify and categorize factors affecting ITO decision in the extant literature. Since scholars employed different titles for the same concept or factor, we needed to code factors. Codification process is conducted by two authors, and the results are displayed in Tables 5 to 8. Coding factors were not done on the basis of the variable titles mentioned in reviewed papers, but they were coded by their inherent meaning and definition. We did our best to ensure that we coded what the authors actually defined and measured. For example, uncertainty has been used in the literature with two different concepts including behavioral and environmental uncertainty. Environmental uncertainty refers to the ambiguity of technology, market needs, and customer requirements. While behavioral uncertainty refers to the problems arising from vendor performance assessment difficulties (Watjatrakul, 2005). Such terms appeared in published articles with different wording. For instance, Alvarez-Suescun (2010) defines uncertainty as problems arising from information asymmetry and ambiguity between client and its vendor. Considering the fact that it is similar in meaning to "performance assessment and control issues", we have organized it into this category. On the other hand, Gerbl et al. (2014) defined uncertainty as a situation in which there is a dynamic customer need, and both outsourcing parties are trying to adopt unpredictable changes over the time which we have coded as "environmental uncertainty". Similarly, Bush et al. (2008) referred to changes in customer needs which we have coded as "environmental uncertainty" too. Furthermore, there were cases in which a single phrase referred to more than one constituting factors. For instance, Gerbl et al. (2014) referred to "client outsourcing capability" which was included and accordingly coded in our research as "availability of required skills and competencies" and "client prior outsourcing experience". The coding process was conducted by two of the authors of the paper, and at the end of the process,

Figure 1. Positioning ITO decision within the ITO literature

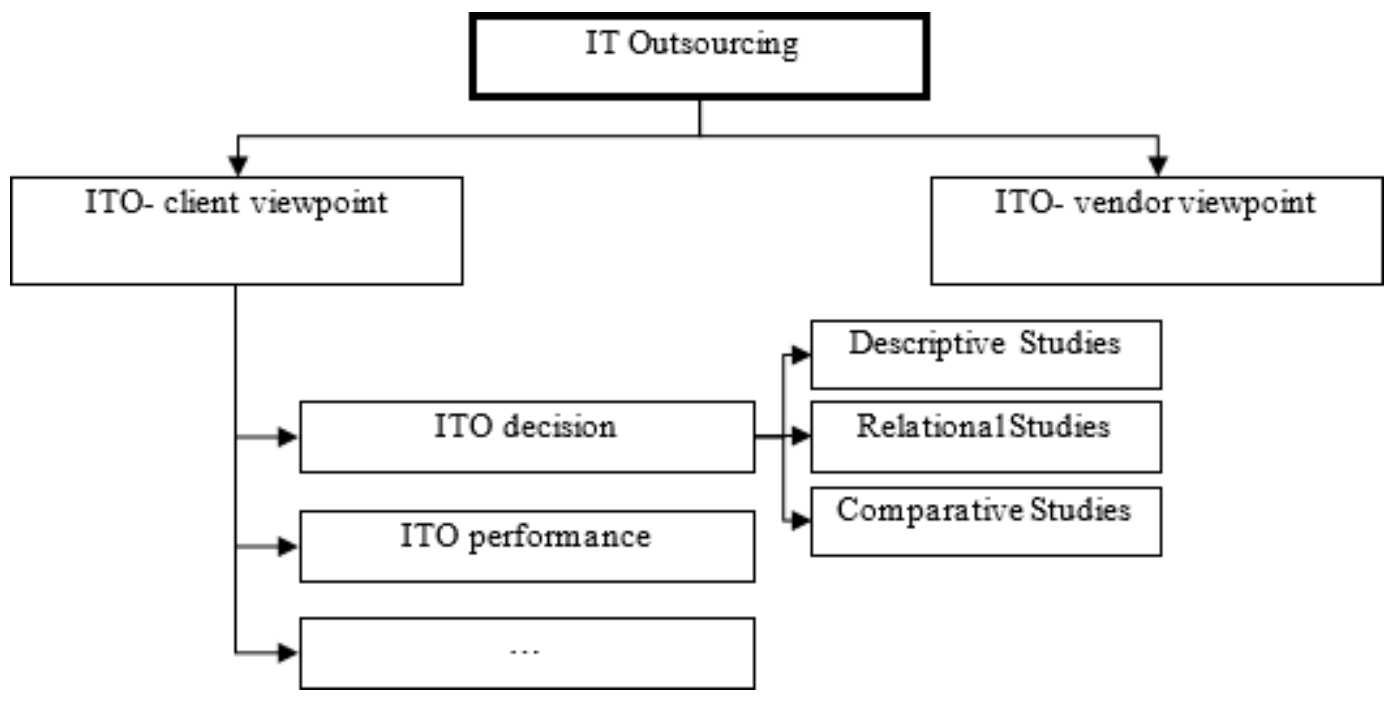


comparison on coded variables was made to explore dissimilarities and achieve consensuses on the title of variables. The factors' brief definition has appeared in Appendix I and the master codes are illustrated in Appendix II.

Finally, to answer $R Q 3$, an attempt has been made to identify investigated ITO strategies in prior research which are conducted by counting strategies studied in the publications each year. Based on research gaps identified in each step mentioned above, future research paths are proposed in section "future paths of research" to answer $R Q 4$.

\section{SYSTEMATIC LITERATURE REVIEW EXECUTION}

By surveying the selected resources, we came up with a total of 315 papers in our results for the primary search. The papers that were totally irrelevant were filtered after the study selection process. After screening the papers in this step, 75 studies from primary search results were left. We then deployed secondary search strategy to ensure the adequacy of our results. We retrieved further 16 studies that were relevant but were missing in our primary search results. After this phase, the total number of included papers raised up to 91 studies published between 2000 and 2018. Figure 2 presents the whole SLR execution process.

\section{ITO DECISION LITERATURE CLASSIFICATION}

This section attempts to provide an answer to the $R Q 1$. Identified ITO decision papers are categorized into three main categories including descriptive, relational, and comparative (adapted from a review of Hanafizadeh et al. (2014)). The descriptive group refers to studies that explore the characteristics and attitudes of ITO clients, barriers to adoption, and the appealing features that lead to an ITO decision. These studies rely on both primary and secondary evidence to describe the nature of ITO decision, but they do not seek out to explain or theorize the relationships between the various factors influencing the decision. The relational studies which have attracted increasing attention in recent years intended

Figure 2. SLR execution process

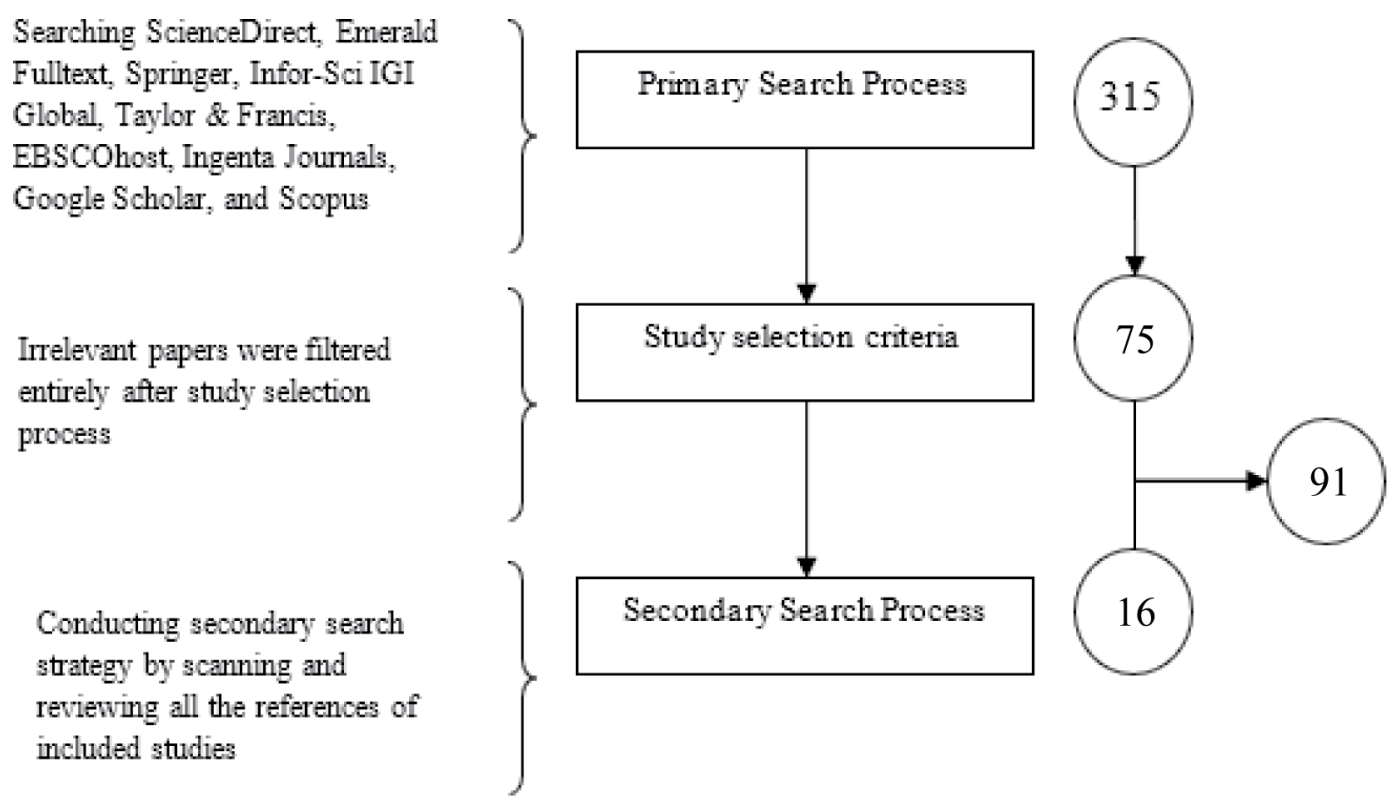


to figure out how different factors that affect ITO decision interact with each other while they exert an influence on ITO decision. The main distinguishing feature of these studies compared to descriptive studies is that they strive to explain and predict the phenomena of ITO decision using models and theories. The comparative group of studies which have been neglected in the literature investigates ITO decision by concentrating on comparisons among key variables. These key variables can be represented by three groups of studies: context, service/process type, and ITO level. The impetus for comparative studies is that the ITO decision is likely to vary based on economic, cultural, social, political, technological, and developmental variables and strategic nature of services and different levels of client ITO level. The majority of the extant ITO decision literature were devoted to relational studies (51\%), followed by descriptive (33\%) and comparative (16\%) (See Appendix II). A total of 51 journals published 91 articles on ITO decision between 2000 and 2018. Table 2 presents the list of our search output according to the journals (only journals with three or more articles reported).

Our findings (Appendix II) disclose that the 91 reviewed publications were conducted in 22 unique countries. Table 3 presents the list of our search output according to the contributed country (only countries with three or more articles reported).

Furthermore, our collection consists of 54 surveys (59\%), 30 case studies (33\%), and seven conceptual models (8\%). Further interpretation of the categories and values are provided in the following sections.

\section{Descriptive Studies}

The primary focus of these studies includes ITO motives, ITO risks, and ITO drawbacks. Following is an overview of some exemplary studies of the descriptive type.

Table 2. ITO studies according to journal titles

\begin{tabular}{|l|l|}
\hline \multicolumn{1}{|c|}{ Journal Title } & Count \\
\hline International Journal of Information Management & 12 \\
\hline Information \& Management & 5 \\
\hline Journal of Global Information Management & 4 \\
\hline Information Systems Frontiers & 4 \\
\hline Journal of Enterprise Information Management & 4 \\
\hline Journal of International Management & 4 \\
\hline The Journal of Strategic Information Systems & 3 \\
\hline Journal of World Business & 3 \\
\hline
\end{tabular}

Table 3. ITO studies according to contributed countries

\begin{tabular}{|l|l|l|l|}
\hline \multicolumn{1}{|c|}{ Country } & \multicolumn{1}{c|}{ Count } & \multicolumn{1}{c|}{ Country } & \multicolumn{1}{c|}{ Count } \\
\hline USA & 20 & India & 6 \\
\hline Germany & 11 & Japan & 3 \\
\hline Multi-national & 11 & France & 3 \\
\hline Taiwan & 9 & Iran & 3 \\
\hline UK & 7 & Saudi Arabia & 3 \\
\hline China & 6 & Spain & 3 \\
\hline
\end{tabular}


By adopting the TOE framework as a theoretical base, in their qualitative exploratory study, Alshamaila et al. (2013) used semi-structured interviews to collect data in 15 different small-medium enterprises (SMEs) and service providers in the northeast of England. The main factors identified as playing a significant role in SME adoption of cloud services were: technological (relative advantage, uncertainty, compatibility, complexity, trialability), organizational (size, top management support, innovativeness, prior IT experience), and environmental (industry, market scope, supplier efforts and external computing support). Other studies merely focused on a narrower context to describe ITO decision. For instance, Brender and Markov (2013) focused on risk and control analysis with a sample of Swiss companies concerning their prospective adoption of public cloud services. In another research surveying 329 Spanish companies, Gonzalez, Gasco, and Llopis (2009) proposed top 10 reasons and 11 main risks of ITO and compared the ranking results in 2001 and 2006. Based on their findings, no dramatic changes seem to have taken place in the interval period. Owing to the fact these studies focused on a specific context, in spite of providing an in-depth insight into that context, there is a slim chance of generalizing the results to other industries, countries, etc. In descriptive studies class, ITO motives or benefits such as scalability, cost savings, access to new technologies, enhanced maintenance and upgrade, focus on core competencies, and flexibility (Kedia \& Lahiri, 2007; Lee, Chae, \& Cho, 2013) are discussed more in comparison with ITO risks and enablers.

\section{Relational Studies}

The relational studies intend to figure out how different factors that affect ITO decision interact with each other while they exert an influence on the decision. The dominant theories in this category are depicted in Table 4 which is further discussed in the following.

Transaction Cost Economics (TCE) has been the most frequently appropriated theoretical framework for the study of ITO. TCE is a theory that addresses make-or-buy decisions explicitly, so it has been viewed as a strong theoretical base for analyzing ITO decisions. TCE has enjoyed an abundance of empirical and theoretical academic attention in other disciplines, which may have also influenced its appeal to ITO researchers (Lacity, Willcocks, et al., 2011). Barthélemy and Geyer (2005) were amongst the first scholars who used this theory to examine some of the determinants of the outsourcing versus quasi-outsourcing decision. Utilizing 160 primary data collected in France and Germany, they proposed that the decision is strongly influenced by both internal (i.e., asset-specificity, size, and internal organization of IT) and external (i.e., institutional environment) determinants. It should be noted that the TCE-based ITO research has led to inconsistent and even unexpected results within studies (Lacity et al., 2016). As an example, Aubert et al. (2004) found the positive influence of asset specificity on the ITO decision while Poppo and Zenger (2002) exposed a negative influence. Miranda and Kim (2006) hypothesized an adverse impact of uncertainty on the proportion of the IT budget being outsourced, but they found a positive relationship contrary to their hypothesis. Several explanations have been proposed for such mixed results such as research methods, boundary conditions, TCE assumption violation explanations, and alternate theory explanations (Lacity, Willcocks et al., 2011). Among the most cited TCE based factors affecting ITO decisions, we can refer to asset specificity, uncertainty, measurement difficulty, transaction frequency, external production cost advantage, and opportunism.

Given the limitations of the TCE model which covers just transaction-related economic and cost parameters in ITO decisions, some scholars employed Resource-Based View (RBV) and Resource dependence theory (RDT). The RBV is regarded as a valuable theoretical framework for analyzing the influence of both firm- and process-level factors such as internal capabilities in ITO and the strategic importance of the process on the ITO decision. The RBV views the firm as a bundle of assets and resources that can bring about a competitive advantage if employed in distinctive ways. The RBV fulfills a significant in the study of ITO as a superior performance that can be achieved in organizational processes relative to competitors would explain why such processes are performed 
internally (Gerbl et al., 2014). While a RBV focuses on the firm completing an internal analysis of capabilities, the RDT recognizes that all organizations are dependent upon the external environment.

TOE framework has been employed in seven of the reviewed studies. This model has been proposed by Tornatzky et al. (1990) to explain the process of innovation in the context of an enterprise. It takes into account three features of an enterprise that impact upon the adoption of innovation as technology, organization, and environment. The technology context refers to the internal and external technology relevant to the organization and the technologies that are available for possible adoption. The organization context refers to the descriptive characteristics of the firm (i.e., organizational structure, firm size, managerial structure, the degree of centralization), resources (human and slack resources), and the process of communication (formal and informal) among employees. The environment context is comprised of the market elements, competitors, and the regulatory environment. The first application of TOE in ITO decision dates backs to Koong's et al. (2007) work in which they categorized factors affecting US organizations' ITO to international vendors under the TOE model categories. Afterwards, other scholars used TOE for investigating factors affecting new emerging strategies such as CC in England (Alshamaila et al., 2013) and Taiwan (Hsu, Ray, \& Li-Hsieh, 2014; Lin \& Chen, 2013; Low, Chen, \& Wu, 2011) contexts. Some scholars tried to merge TOE with other models such as Human-Organization-Technology fit (HOT-fit) to provide a more inclusive model (e.g., Lian, Yen, \& Wang, 2014).

Diffusion of Innovation (DoI) is a prominent adoption model in IS literature. It proposes five attributes that explain the adoption of innovation in an organization. They are: 1) relative advantage, the extent to which an innovation is superior to its previous generation; 2) compatibility, the degree to which an innovation can be assimilated into the existing business processes, practices, and value systems; 3) complexity, the level of difficulty to use the innovation; 4) observability, extent to which the innovation is visible to others; and 5) trialability, the ease of experimenting with the innovation. DoI is a popular model for investigating the adoption of innovation in organizations and especially can explain the individual level adoption process in the pre-adoption and adoption-decision stages of innovation adoption. However, it has received substantial criticism in its application at an organizational level (Hameed, Counsell, \& Swift, 2012b). One of the major limitations of DoI is that it applies an individualist level and ignores the influence of organizational and environment factors (M. K. O. Lee \& Cheung, 2004). Furthermore, DoI does not address the full implementation process of IT. The model provides no rationale for determining whether the innovation is put into use by the adopter. However, there is only two previous research in the field of ITO decision using this theory (Oliveira, Thomas, \& Espadanal, 2014; Y. Wu, Cegielski, Hazen, \& Hall, 2013) which deserves more studies in the future.

Technology Acceptance Model (TAM) is an adaptation of Theory of Reasoned Action (TRA) introduced by Davis (1989) and aims at predicting user acceptance of IT and explains the behavior of individuals in IT acceptance. TAM hypothesizes that IT adoption has two perceived attributes that influence user adoption, namely "perceived usefulness" and "perceived ease of use". Afterward, the original TAM has been evolved into TAM2 (Venkatesh, 2000), Unified Theory of Acceptance and Use of Technology (UTAUT) (Venkatesh, Morris, Davis, \& Davis, 2003), and TAM3 (Venkatesh $\&$ Bala, 2008). The original TAM has been used in ITO decision literature by Wu (2011a) for SaaS and by Benamati and Rajkumar (2008) for software development outsourcing decision. Although evolved models of TAM have been used in IT innovation adoption, such studies are considered as ITO decision. Among factors that can be investigated based on the TAM2 and TAM3, we can refer to subjective norms, job relevance, output quality, result demonstrability, personnel image and previous experience. Additionally, based on UTAUT, performance expectancy, effort expectancy, social influence, facilitating conditions, and demographic factors such as age, gender, experience, and voluntariness of use could be proposed.

Agency theory argues that, in a principal-agent relationship, the agent (the external vendor) cannot entirely implement the goals set up by the principal (the client). Although 
agency theory was initially conceptualized at the individual level of analysis, it has previously been applied to understand principal-agent conflicts in inter-firm relationships such as outsourcing alliances. The concept of information asymmetry is central to principal-agent models: the agent is assumed to possess private information that the principal is only able to acquire with added cost and effort. Choudhury and Sabherwal (2003) have found that agency problems are indeed more pronounced in outsourced software development projects relative to internal projects, reinforcing the assertion of information asymmetry among clients and vendors in ITO arrangements. Therefore, the extent to which a client can overcome such information asymmetry at the project level should influence the degree to which ITO is considered viable by client IT managers. Tiwana and Bush (2007) in their studies, using agency theory investigated the effect of project outcome measurability and vendor behavior observability on ITO decision.

In the relational studies category, some scholars have merely tried to study the factors affecting ITO decisions by using a distinct theory rather than intending to propose a more comprehensive model based on two or more supporting theories. For instance, Chou et al. (2006) using social capital theory, investigated a high-tech company in Taiwan context and explored the effects of network ties, network configuration, appropriable organization, trust, norms, obligation, identification, shared codes and language, and shared narratives on ITO decision.

In other studies (e.g., Jayatilaka, Schwarz, \& Hirschheim, 2003; Tiwana \& Bush, 2007), knowledge-based theories and related factors such as knowledge availability in client/vendor side, requirements specifiability or requirements volatility were explored. However, it can be implied that ITO could lead to knowledge loss in client side because the client might lose skills and knowledge required to do the tasks internally throughout the ITO period. However, such arguments call for empirical investigations on longitudinal datasets.

Based on the review results, it can also be claimed that 12 out of 45 relational studies (see Table 4) have employed no specific theory in their proposed conceptual model and suggested a set of factors affecting ITO decisions without using any ground theories or frameworks.

Table 4. Distribution of papers by underlying theories

\begin{tabular}{|l|l|l|l|}
\hline \multicolumn{1}{|c|}{ Theory } & Count & \multicolumn{1}{c|}{ Theory } & Count \\
\hline Transaction cost economics (TCE) & 12 & Social capital theory (SCT) & 1 \\
\hline Resource-based view theory (RBV) & 7 & Competitive forces & 1 \\
\hline Technology-Organization-Environment (TOE) & 7 & Dunning's eclectic theory & 1 \\
\hline Technology Acceptance Model & 6 & Social cognitive theory & 1 \\
\hline Risk -benefits framework (RBF) & 4 & Opportunity Risk framework & 1 \\
\hline Institutional theory & 3 & Theory of Reasoned Action (TRA) & 1 \\
\hline Innovation diffusion theory (DoI) & 3 & Organizational capability theory & 1 \\
\hline Agency theory & 3 & Relational Exchange Theory & 1 \\
\hline Resource dependence theory (RDT) & 2 & Two-factor theory (enablers/ inhibitors) & 1 \\
\hline Strategic Management Theory & 2 & Production costs economics (PCE) & 1 \\
\hline Knowledge-based perspective (KBP) & 1 & Theory of Planned Behavior (TPB) & 1 \\
\hline Corporate Social Responsibility & 1 & Institutional Economics & 1 \\
\hline Incomplete contracts theories & 1 & NOT specific theory & 12 \\
\hline
\end{tabular}




\section{Comparative Studies}

The first research in this category during the period is the study of Barthélemy and Geyer (2005) in which they conducted a cross-sectional survey for collecting primary data from a group of 160 large French and German firms to examine some of the determinants of the outsourcing versus quasioutsourcing decision. They showed that the decisions were strongly influenced by both internal (i.e., asset- specificity, size, and internal organization of IT) and external (i.e., institutional environment) determinants. Moreover, they found that IT quasi-outsourcing more frequently occurred in Germany than in France. Although they surveyed a good sample size with a variety of industries covered, the generalizability of their results are limited due to the following reasons: 1) they solely focused on the outsourcing versus quasi-outsourcing alternative, 2) they merely addressed the two developed countries, and 3) their research was cross-sectional, and it is impossible to determine whether firms are increasing, decreasing, or keeping their current ITO level. In another research, based on the innovation characteristics from the DoI theory, and the TOE framework, Oliveira et al. (2014) investigated the determinants of $\mathrm{CC}$ adoption in the manufacturing and services sector using a surveyed data from 369 firms in Portugal.

Another set of comparative studies probed the effect of service/process type. For instance, Benlian et al. (2009) investigated SaaS adoption of three candidate ERP, CRM and Office application in Germany. In the third set of studies in this category, the effect of independent variables on the dependent variable (ITO decision) for different ITO levels or ITO strategies has been explored. For instance, Gewald and Dibbern (2009) examined the effect of perceived benefits and perceived risks on ITO decisions in three kinds of banks: 1) "Pro" The bank has already outsourced the process. 2) "Neutral" The outsourcing option is currently under investigation. 3) 'Contra"' The bank decided against outsourcing the process. The results implied difference among three categories regarding perceived benefits and risks. In another study, using questionnaires from 106 hospital CIOs in Taiwan, Lian et al. (2014) investigated the level of human (Chief Executive Officer (CEO) innovativeness, perceived technical competencies), technology (security, complexity, compatibility, costs), organizational (relative advantage, top management support, adequate resource, benefits), and environment (Regulations and government policies, perceived industry pressure) factors in four types of innovator, early adopters, majority, and rejecter hospitals. Hospitals that have completed the development of $\mathrm{CC}$ technology are considered as innovators. Hospitals that are currently developing their CC platform are regarded as the early adopters. Most research subjects are still assessing the need to adopt this new platform and hence, they will be grouped under the "majority" category. Finally, rejecters are those who have decided not to adopt CC. This study indicates that there is a significant difference among hospitals about different outsourcing level. For example, there is a significant difference between innovators and rejecters regarding perceived industry pressure.

\section{FACTORS AFFECTING ITO DECISION}

This section attempts to provide an answer to the $R Q 2$ regarding identifying factors that impact upon ITO decision. ITO decision can be viewed as a multi-faceted concept (Hanafizadeh \& Zare Ravasan, 2017). Tornatzky et al. (1990) introduced technology, organizational, environmental (TOE) model to model factors that affect technology-based innovations. Organizational level adoption models like ITO decision models might embrace user acceptance related factors which mainly arises from user behavior-centric theories such as TAM, TRA, and TPB (Hameed et al., 2012b). Accordingly, based on the original TOE model and by including new user category, factors affecting ITO decision are classified into four categories of technology, organizational, environmental and user (TOEU). TOE has been selected here, for the following reasons: 
1. There are theoretical models which focus on specific aspects of ITO decisions (i.e., Transaction Cost Economics (TCE), Resource-Based View (RBV), Diffusion of innovations (DoI), etc.). TOE has more holistic and multifaceted view on ITO decisions which consider technological, organizational and environmental factors simultaneously (Hanafizadeh \& Zare Ravasan, 2017);

2. Given the capability of the TOE model in covering a wider set of factors affecting adoption decisions, its application in the ITO decision studies has been suggested in previous research (e.g., Lian et al., 2014; Low et al., 2011);

3. Although various factors affect ITO adoption, all these factors can be classified in technological, organizational, or environmental contexts (Côrte-Real, Ruivo, Oliveira, \& Popovič, 2019; Hanafizadeh \& Zare Ravasan, 2018b). Thus, it is feasible to apply the TOE model to categorized ITO decision determinants.

The relationship coding scheme between these independent factors (i.e., TOEU factors) and dependent factor (i.e., ITO decision) (see Tables 5 to 8 ) assigned four possible values to the relationships: ' +1, ' ' -1, ' ' 0 ,' and 'NT'. We coded a ' +1 ' for positive relationships, '- 1 ' for negative relationships, ' 0 ' for relationships that were studied but not empirically significant. Positive relationships signified when higher values of an independent variable were associated significantly with higher values of a dependent variable. Negative relationships indicate a time when higher values of an independent variable were significantly associated with lower values of a dependent variable. If the study was quantitative, $\mathrm{P}<0.05$ was used as the requirement for a significant positive or negative relationship. If the study was qualitative, the authors' strong argument for a significant positive or negative relationship was not taken account. Also, an 'NT' was used for not empirically tested relationships. Besides, studies which have just proposed a conceptual model or where there is no consensus on the relationship between independent and dependent variables due to, for instance, the type of service (i.e., strategic, propriety) or different countries and contexts are assigned to this category. Furthermore, to extract concise, meaningful, and helpful findings across the literature, we counted the number of times a relationship between an independent and dependent variable was studied and the number of times it was found to be positively significant, negatively significant, insignificant, or that a relationship not tested or not resulted in a unique result. We created a model by extracting the most frequently examined variables that produced consistent results across studies, using the rules that the variable had to be empirically examined at least five times and that at least $60 \%$ of evidence had to be consistent.

\section{Technology Factors}

Technology category refers to innovation or technology characteristics (ITO in here) which influence the decision to adopt. These factors are summarized in Table 5. Among these factors, only two factors of perceived benefits and perceived risks involve detailed items which are all embraced under their associated factors. Perceived benefits include items such as scalability, cost saving, access to new technologies and methods, enhanced maintenance and upgrade, focus on core competencies, and flexibility (Kedia \& Lahiri, 2007). Also, perceived risks incorporate financial, performance, psychological, strategic, economic and political risks (Gewald \& Dibbern, 2009; Graf \& Mudambi, 2005). As can be seen from the Table 5, nine out of 18 identified variables in this category have been empirically examined at least five times and for eight cases, we observed at least $60 \%$ of consistency.

Regarding our review, perceived benefits of ITO was the most studied factor in this category which provided strong, consistent results. 34 out of 40 studies found a positive relationship between perceived ITO benefits and ITO decision. Benefits can be divided into two main sections including tangible and intangible. Tangible benefits are those directly related to gain dollar figure in organizations such as time and cost savings. Intangible benefits are those difficult or sometimes impossible to quantify. Intangible benefits include the focus on core competencies, access to specialized resources, quality 
Table 5. Relationships between technology variables and ITO decisions

\begin{tabular}{|c|c|c|c|c|c|c|c|}
\hline Id & Factor Title & +1 & -1 & $\mathbf{0}$ & Sum* & NT & Total \\
\hline T01 & Perceived benefits & 34 & 1 & 5 & 40 & 9 & 49 \\
\hline T02 & Perceived risks & 0 & 22 & 2 & 24 & 6 & 30 \\
\hline T03 & Performance assessment and control issues & 0 & 8 & 5 & 13 & 5 & 19 \\
\hline T04 & Perceived complexity & 0 & 10 & 4 & 14 & 1 & 15 \\
\hline T05 & Perceived security & 12 & 0 & 3 & 15 & 4 & 19 \\
\hline T06 & Consistency & 10 & 0 & 5 & 15 & 1 & 16 \\
\hline T07 & Asset specificity & 7 & 1 & 1 & 9 & 4 & 13 \\
\hline T08 & Service strategic nature & 0 & 2 & 5 & 7 & 2 & 9 \\
\hline T09 & Perceived cost & 0 & 11 & 1 & 12 & 3 & 15 \\
\hline $\mathrm{T} 10$ & Data protection issues & 1 & 3 & 0 & 4 & 0 & 4 \\
\hline $\mathrm{T} 11$ & Perceived privacy & 4 & 0 & 0 & 4 & 4 & 8 \\
\hline $\mathrm{T} 12$ & Integration issues & 0 & 2 & 2 & 4 & 1 & 5 \\
\hline $\mathrm{T} 13$ & Trialability & 2 & 0 & 2 & 4 & 3 & 7 \\
\hline $\mathrm{T} 14$ & Lack of proper and in-place standards & 0 & 1 & 2 & 3 & 0 & 3 \\
\hline $\mathrm{T} 15$ & Transaction frequency & 1 & 0 & 1 & 2 & 1 & 3 \\
\hline T16 & Service/ Process complexity & 1 & 1 & 1 & 3 & 0 & 3 \\
\hline $\mathrm{T} 17$ & Business process IT detachability & 1 & 0 & 0 & 1 & 0 & 1 \\
\hline $\mathrm{T} 18$ & Business process modularity & 1 & 0 & 0 & 1 & 0 & 1 \\
\hline
\end{tabular}

${ }^{*}$ In the sum column, the bolded text refers to factors that have been empirically examined at least five times; the italicized text denotes at least $60 \%$ of consistency.

improvements and so on (Lacity \& Willcocks, 2000). Both tangible and intangible benefits affect the decision to adopt ITO and can be utilized in this context.

Perceived risks are the second most widely studied factor in this category in which 22 out of 24 studies suggested negative effects of that on ITO decision. Perceived risks have been found to influence adoption behavior in various ways. Previous IS research indicated that perceived risk influences the adoption decision of new IT systems and innovations (Gewald \& Dibbern, 2009). Taken together, the influential role of perceived risks in adoption processes in general and in ITO decisions, in particular, is widely supported with strong consistency at the organization level.

Complexity is another major determinant of ITO. Based on the TCE theory, complexity refers to the degree to which an innovation is perceived as difficult to use and understand in the business environment (Lin \& Chen, 2013). Regarding ITO, complexity concerns the extent to which the outsourcing task is sophisticated and difficult to standardize, requiring a great deal of specialized knowledge to undertake the task. In simpler terms, complexity shows the difficulty in adopting an innovation, which may be presumed as the inverse of perceived ease of use in technology adoption research (Davis, 1989). The ITO complexity can arise from contract governance issues, pricing mechanisms, adopting and using new outsourcing options like cloud computing and Software as a Service (SaaS) (Hanafizadeh \& Zare Ravasan, 2018b).

12 out of 15 studies proposed a positive relationship between perceived ITO security and ITO decision. When the IT function is outsourced to an external service provider, the organization no longer retains full control of information security whereas full control is retained when the IT function 
is provided in-house. With this regard, it is very critical that organizations make sure that vendors have adequate security/privacy measures in place.

Concerning our review, consistency is another major determinant of ITO decision. Consistency is the degree to which ITO is perceived as consistent with the existing values, strategies, legacy systems, and needs of potential adopters (Alshamaila et al., 2013). When, low level of consistency perceived in an organization aimed at ITO, negative resistances arise which can adversely affect ITO outcomes.

Asset specificity is another major determinant of ITO decision which suggested moderately consistent level on the relationship between asset specificity and ITO decision. Asset specificity is the degree to which assets needed for the transactional relationship are not transferable to other activities or relationships. In term of outsourcing, low asset specificity indicates that assets required for the process do not have to be tailored to a given transactional relationship and both vendors and clients can easily find other partners. The results between the degree of asset specificity and outsourcing level are not conclusive in previous research. For example, in the presence of specific assets, Barthelemy and Geyer (2005) observed that firms used subsidiaries instead of relying on ITO. Loebbecke and Huyskens (2006) and Aubert et al. (2012) could not find support for the role of asset specificity in the ITO decision. On the contrary, Aubert et al. (2004) and Hanafizadeh and Zare Ravasan (2018a) found asset specificity to be positively linked to ITO. Ellram et al., (2008) argued that the more specific the assets required to support an activity, the less likely that firm is to outsource that activity. Such activities are not good candidates for ITO because the firm could develop a high level of dependence on the supplier, and the supplier could then show opportunistic behavior, raising prices, reducing service levels, or the like. In cases where the supplier owns the specific assets, the supplier is subjected to the potentially significant risk associated with accepting the activity.

With regard to our review, service strategic nature is not significantly related ITO decision. According to Gilley and Rasheed (2000), there are two types of outsourcing as peripheral and core process/service. Outsourcing peripheral activities allow firms to focus on those activities they do best. This allows the firm to become more innovative and agile in its core domain as well as help improve the quality of outsourced service and diminishing associated costs (2010). On the other hand, outsourcing core or near-core strategic activities may lead to declining innovation and reduced firm performance. One interpretation of this argument might be that the perceived strategic importance of a process/service to the firm has simply a moderating rather than direct effect on ITO decisions (Hanafizadeh \& Zare Ravasan, 2018b).

Based on the results of our review, perceived cost demonstrated a consistent negative relationship with ITO decision. From innovations costs perspective, the advantages of each innovation should exceed the costs of adopting it. Therefore, the costs of innovation have a major bearing on the decision to its adoption (Lu, Lin, \& Tzeng, 2013). In this respect, ITO is no exception. This subject not only approaches the details related to ITO costs, but also collects issues related to "hidden" costs such as search cost, transition cost, and beyond-baseline service (Tafti, 2005). In some situations, such as lock-in of ITO relationship, changes in contracts, unexpected events, and disputes and litigation, the adoption cost of the outsourcing service becomes a critical concern (Koong et al., 2007). In general, firms would like to maintain the balance between both benefits and costs associated with the adoption of innovation (Teo, Lin, \& Lai, 2009). Regarding ITO, costs include the total cost of ownership, cost of excess capacity of resources, integration costs, future service innovation costs, labor costs related to service maintenance, cost of potential future service provision changes and so on.

\section{Organizational Factors}

Organizational factors are related to organizational features and characteristics which a new technology or innovation (ITO in here) adopting firm possesses. Table 6 summarizes the 25 identified factors in the organizational category. In IT adoption literature, managerial characteristics with a focus on managerial features and demographic information have been considered and studied under the organizational category or even under a distinct category of managerial characteristics. Among 
Table 6. Relationships between organizational variables and ITO decisions

\begin{tabular}{|c|c|c|c|c|c|c|c|}
\hline Id & Factor Title & +1 & -1 & $\mathbf{0}$ & Sum & NT & Total \\
\hline $\mathrm{O} 01$ & Availability of required skills and competencies & 11 & 0 & 3 & 14 & 1 & 15 \\
\hline $\mathrm{O} 02$ & Trust & 9 & 0 & 1 & 10 & 2 & 12 \\
\hline $\mathrm{O} 03$ & Size & 4 & 1 & 8 & 13 & 0 & 13 \\
\hline O04 & Client prior outsourcing experience & 7 & 0 & 1 & 8 & 2 & 10 \\
\hline O05 & Positive attitude towards ITO & 6 & 0 & 0 & 6 & 1 & 7 \\
\hline O06 & Top management support & 11 & 0 & 2 & 13 & 0 & 13 \\
\hline O07 & Organizational knowledge level & 0 & 2 & 1 & 3 & 1 & 4 \\
\hline O08 & IT department size & 3 & 1 & 0 & 4 & 0 & 4 \\
\hline O09 & Technological readiness (IT infrastructure) & 4 & 1 & 4 & 9 & 4 & 13 \\
\hline $\mathrm{O} 10$ & Requirements specifiability & 6 & 0 & 1 & 7 & 0 & 7 \\
\hline O11 & Top management/organizational innovativeness & 4 & 0 & 0 & 4 & 1 & 5 \\
\hline $\mathrm{O} 12$ & IT department budget & 1 & 2 & 0 & 3 & 0 & 3 \\
\hline $\mathrm{O} 13$ & Bounded rationality of organization & 0 & 0 & 1 & 1 & 1 & 2 \\
\hline O14 & Lack of qualified employees to do the tasks in-house & 1 & 0 & 1 & 2 & 0 & 2 \\
\hline O15 & IT budget development & 0 & 0 & 1 & 1 & 0 & 1 \\
\hline O16 & Internal resistance to ITO & 0 & 2 & 0 & 2 & 0 & 2 \\
\hline O17 & Obligations for ITO & 0 & 0 & 2 & 2 & 0 & 2 \\
\hline O18 & Poor firm-level financial performance & 1 & 0 & 0 & 1 & 0 & 1 \\
\hline O19 & CEO compensation & 1 & 0 & 0 & 1 & 0 & 1 \\
\hline $\mathrm{O} 20$ & CIO skills & 1 & 0 & 0 & 1 & 0 & 1 \\
\hline $\mathrm{O} 21$ & Knowledge loss & 0 & 2 & 0 & 2 & 1 & 3 \\
\hline $\mathrm{O} 22$ & Management style & 2 & 0 & 0 & 2 & 0 & 2 \\
\hline $\mathrm{O} 23$ & Vendor management capacity & 2 & 0 & 0 & 2 & 0 & 2 \\
\hline $\mathrm{O} 24$ & Business level strategy & 0 & 0 & 1 & 1 & 0 & 1 \\
\hline $\mathrm{O} 25$ & Industry type & 1 & 0 & 1 & 2 & 0 & 2 \\
\hline
\end{tabular}

${ }^{*}$ In the sum column, the bolded text refers to factors that have been empirically examined at least five times; the italicized text denotes at least $60 \%$ of consistency.

these factors, we can refer to manager's age, sex, education level, managerial tenure, and attitude towards innovation (Chuang, Nakatani, \& Zhou, 2009). Based on the results of Table 6, regarding ITO decision, manager's IT knowledge, tenure, age, sex, and education level have been overlooked in the extant literature. As can be seen from the Table 6, eight out of 25 identified variables in this category have been empirically examined at least five times. Among these, for seven variables, we observed at least $60 \%$ of consistency while we have not found such consistency in one variable, i.e., technological readiness.

Availability of required skills and competencies is the major ITO determinant identified in this review. Some previous indicate that a firm with a higher level of IT capabilities and competencies is more likely to adopt new technology (Hameed, Counsell, \& Swift, 2012a; Hsu et al., 2014). Nevertheless, when discussing ITO, some believe that firms with lower IT capability may be more likely to outsource, a view diametrically opposed to the findings of some past studies (Hofmann \& Woods, 2010; e.g., Lian et al., 2014; Sultan, 2011) which proposed that organizations with adequate IT resources are more likely to adopt CC as an option to outsource IT services. However, there is little evidence to generalize which kinds of firms regarding the availability of required skills and 
competencies are more or less likely to outsource. To sum up, it can be suggested that there might be a U-shaped relationship between the availability of required resources and ITO decision. Meanwhile, organizations with more or fewer skills and competencies are more likely to outsource rather than organizations with the moderate level of skills and competencies. Such arguments could be empirically investigated in the future research.

Results of our review illustrated that trust was another major determinant of ITO, positively affects ITO decisions. When ITO contracts are initiated, relationship strength may cover the implicit part of the exchange that leads to setting up patterns of activities in dealing with issues of ITO exchange. Relationships based on trust between the parties strengthen the bond between clients and their service providers (Becerra, Lunnan, \& Huemer, 2008). Establishing strong, trustworthy relationship results in effective governance by facilitating mutual understanding between parties (Vivek, Richey Jr, \& Dalela, 2009). There is also evidence showing that outsourcing projects in the 1990s shifted from contractual to trust-based relationships (Kim, Lee, Koo, \& Nam, 2013).

Client prior ITO experience serves as another major determinant of ITO decision. Many ITO decisions are not independent decisions; instead, they rest on prior ITO experiences (Benamati \& Rajkumar, 2008). There exists a relationship between a firm's prior knowledge and their understanding of a new context or situation (Alshamaila et al., 2013). Past marketing research found that customer satisfaction with prior working experiences with a provider affected their loyalty to that provider. The strength of the relationship increased with the length of prior experience in such cases (Benamati \& Rajkumar, 2008). In the case of ITO, being familiar with ITO strategies and past positive experiences can have a direct influence on managers' ITO perceptions. Several studies have found prior experience to be important in technology adoption decisions (Hanafizadeh \& Zare Ravasan, 2018a), especially in ITO where, it has been estimated that almost $50 \%$ of all ongoing ITO contracts are discontinued in favor of either using a different vendor or bringing the work back in-house (back-sourcing) (Whitten, Chakrabarty, \& Wakefield, 2010). Consequently, it sounds sensible to claim that organizations' prior experience plays a facilitative role in the ITO decision.

Positive attitude towards ITO is another major determinant of ITO decision. In the TPB, the attitude toward the behavior is proposed to influence the actual behavior, as it integrates different relevant beliefs about the outcome expectations of the decision options (Benlian et al., 2009). A decision-maker on ITO thus shapes an attitude based on beliefs about factors such as the cost-benefit evaluations, complexity, risks, and so forth.

Another major determinant of ITO decision is top management support. According to some recent studies, top management commitment/support is by far the most important success factor in ITO (Lacity, 2018). Top management commitment/support provides both encouragement and resources (e.g., human, time, skills). Regarding ITO, such support is crucial since it is unsettling for the individual employee's point of view as their situation is unclear. Their minds might be obsessed with questions like: Will they be transferred to the outsourcing vendor or even worse? Will they be made redundant? Such situations consequently stimulate human resources to start looking for jobs elsewhere. Then, practitioners should seek for engaging top management in ITO decisions and gain his/her full support (Hanafizadeh \& Zare Ravasan, 2018a).

Requirements specifiability is defined as the ease with which project requirements can be wholly and accurately conveyed to a vendor at the beginning of the project through a formal project specifications document (Tiwana \& Bush, 2007). Low levels of requirements specifiability or in another term, uncertainty in requirements implies that the organization really does not know what it wants from the process. Firms, like people, will set resources aside to cope with unplanned contingencies. In economic terms, this is bounded rationality-there are too many issues for a human to comprehend and effectively address. The managers' in-depth understanding of the firm's business needs and requirements can encourage a supplier to engage in information sharing and communication activities. This will also increase the level of collaborative participation between the client and the supplier. If a firm has a process with uncertain requirements, managers may choose 
to keep that process in house because doing so retains control of unanticipated benefits and costs (Hanafizadeh \& Zare Ravasan, 2017). Meanwhile, by outsourcing such processes, the firm may be limiting its options or flexibility.

\section{Environmental Factors}

Environmental context is the arena in which a firm conducts its business-its industry, competitors, and dealings with the government (Tornatzky et al., 1990). Environmental factors are believed to have significant effects on ITO decisions, however, in the context of offshore ITO, more concerns arise such as political, legal, social, and economic issues. Recently, some scholars have investigated issues like tax rate, investment motives, market maturity, geo-distance between source and destination company, and cultural distances between vendor and client as factors affecting offshore ITO initiatives (e.g., Chen \& Lin, 2018; Graf \& Mudambi, 2005). Table 7 summarizes relationships between environmental variables and ITO decisions. As can be seen from the table, six out of 16 identified variables in this category have been empirically examined at least five times. Among these, for four variables, we observed at least $60 \%$ of consistency while we have not found such consistency in case of two variables: Partners' pressure, and environmental uncertainty.

Competitive pressure is the most frequently studied factor in this category which refers to perceived pressure from business competitors that encourage a firm to adopt new technology for the sake of maintaining competitiveness. Koong, Liu, and Wang (2007) discussed that businesses with higher competitive environment are more likely to turn to new technology to achieve a competitive advantage. Low et al. (2011) for instance, in the context of ITO, asserted that competitors pressure exerts significant influence on the adoption of cloud computing.

Regulations and government policies is another frequently studied factor in this category. Eight out of 13 reviewed studies suggested a consistent positive relationship between this factor and ITO decision. Regulations and government policies mean that governmental support requires a firm or motivate it to adopt ITO. Regulations and government policies exert an important influence on location attractiveness (especially in offshore/near-shore outsourcing) including factors such as tax rates, employment legislation, and government investment in infrastructure, education, and general skills development. Employment and social regulation have often been used as important levers used by governments to enhance their attractiveness (Gerbl et al., 2014).

Table 7. Relationships between environmental variables and ITO decisions

\begin{tabular}{|l|l|c|c|c|c|c|c|}
\hline \multicolumn{1}{|c|}{ Id } & \multicolumn{1}{|c|}{ Factor Title } & $\mathbf{+ 1}$ & $\mathbf{- 1}$ & $\mathbf{0}$ & \multicolumn{1}{|c|}{ Sum } & NT & Total \\
\hline E01 & Competitive pressures & 10 & 1 & 5 & $\mathbf{1 6}$ & 4 & 20 \\
\hline E02 & Regulations and government policies & 8 & 0 & 5 & $\mathbf{1 3}$ & 2 & 15 \\
\hline E03 & Environmental uncertainty & 4 & 3 & 1 & $\mathbf{8}$ & 3 & 11 \\
\hline E04 & Social effects & 5 & 0 & 1 & $\mathbf{6}$ & 2 & 8 \\
\hline E05 & Cultural distance among partners & 0 & 5 & 0 & $\mathbf{5}$ & 3 & 8 \\
\hline E06 & Partners' pressure & 4 & 0 & 3 & 7 & 0 & 7 \\
\hline E07 & Market maturity & 4 & 0 & 0 & 4 & 1 & 5 \\
\hline E08 & Social norms & 2 & 0 & 0 & 2 & 2 & 4 \\
\hline E09 & Opportunistic behavior of vendors & 0 & 1 & 1 & 2 & 1 & 3 \\
\hline E10 & Geo-distance between client and vendor & 0 & 3 & 1 & 4 & 1 & 5 \\
\hline E11 & Client-side infrastructures & 2 & 0 & 0 & 2 & 0 & 2 \\
\hline E12 & Vendor support & 1 & 0 & 0 & 1 & 0 & 1 \\
\hline E13 & Taxation issues & 0 & 1 & 0 & 1 & 1 & 2 \\
\hline E14 & Investment motives & 0 & 0 & 0 & 0 & 1 & 1 \\
\hline E15 & Vendor power & 2 & 0 & 0 & 2 & 1 & 3 \\
\hline E16 & Human capital & 1 & 0 & 0 & 1 & 0 & 1 \\
\hline
\end{tabular}

* In the sum column, the bolded text refers to factors that have been empirically examined at least five times; the boxed text denotes at least $60 \%$ of consistency. 
Social effects factor is another major determinant of ITO decision with more than 80 percent consistent results. Social influence can be defined as the degree to which an individual perceives it is important that others believe they should use a new system. Social influence regarding ITO refers to employees' and managers' intention to adopt ITO based on the influence of people or even firms around them, which have a positive relationship with ITO decisions.

Cultural distance among partners is another major determinant of ITO decision. The effective management of an outsourcing contract hinges on the judgment of the partner's culture (Hanafizadeh \& Zare Ravasan, 2018b). Since the influence of culture is often bidirectional, mutual understanding of each other's cultural issues is conducive to better management of the outsourcing relationship as well. Cultural differences manifest in the form of diverse employee's values and norms, attitudes towards technology, customers, interpersonal contact and interaction, and overall role perception (Graf \& Mudambi, 2005). Norms for customer service differ across countries and even firms. For example, if the organizational culture is hierarchical, then customer service representatives may be less empowered to take the initiative to solve customer problems. Extant literature on cross-cultural variations has pointed out how cultural distance may negatively influence the relationship between outsourcing partners, cross-border knowledge and technology transfer, collaborative learning, and alliance performance (Kedia \& Lahiri, 2007).

\section{User Factors}

ITO decision can also be considered from the organizational and user view (Hameed et al., 2012b). Factors reviewed in the three previous sections (TOE factors) formulate the organizational side. While the innovation-decision can generally be studied from the user perspective in two ways: 1) user innovation adoption for personal use (e.g., mobile, e-banking, social networks, online tools) and 2) user innovation adoption for organizational use (e.g., Enterprise Resource Planning (ERP) adoption). Concerning the purpose of this research, the first theme is beyond the scope of this paper because ITO is an organizational phenomenon rather than personal issue or use concern. User in this category refers to a person or group of them that are supposed to involve in ITO decision as well as stakeholders involved or interested in ITO process and outcomes (e.g., top-level managers, middle-level managers, IT managers, CIOs, sourcing managers, etc.). Theories such as TRA, TAM, and TPB have been used in user adoption studies. Based on the results of this review, user factors in the context of ITO decision have been neglected in the extant literature. Among these factors, we can refer to perceived ease of use and perceived usefulness based on the TAM (Benamati \& Rajkumar, 2008; Ratten, 2014; W.-W. Wu, 2011b). However, other factors such as user/employees attitudes towards outsourcing, past positive/negative experiences, training, employees' involvement, financial motives, and technical support could be of great value for research. Table 8 summarizes the list of user factors in the context of organization ITO decisions. As can be seen from the table, just one (perceived ease of use) out of three identified factors has been counted more than five times, with a consistency rate of 100 percent. According to the TAM, perceived ease of use helps determine an individual's perceptions about the ease of using a technological innovation (Venkatesh, 2000). Perceived ease of use is a driver of the adoption of technological innovations (Ratten, 2014). Some technological innovations are hard to

Table 8. Relationships between environmental variables and ITO decisions

\begin{tabular}{|l|l|c|c|c|c|c|c|}
\hline \multicolumn{1}{|c|}{ Id } & \multicolumn{1}{|c|}{ Factor Title } & $\mathbf{+ 1}$ & $\mathbf{- 1}$ & $\mathbf{0}$ & Sum & NT & Total \\
\hline U01 & Perceived ease of use & 6 & 0 & 0 & $\mathbf{6}$ & 1 & 7 \\
\hline U02 & Perceived usefulness & 4 & 0 & 0 & 4 & 1 & 5 \\
\hline U03 & User innovation & 2 & 0 & 0 & 2 & 0 & 2 \\
\hline
\end{tabular}

* The italicized text denotes at least $60 \%$ of consistency. 
use because of the knowledge required to learn how to use them. In case of ITO, when users have the competence to use outsourced services easily, they will positively accept that.

\section{Concluding Factors Affecting ITO Decisions}

Based on the results of the review, factors affecting ITO decisions yielded 62 factors categorized into four categories of technology, organizational, environmental, and user (see Figure 3). Also, 375 positive, negative and non-significant relationships between dependent and independent variables were identified. As explained before, variables that empirically examined at least five times, with at least $60 \%$ of consistency have been considered as significant factors in ITO decisions. Positive/negative evidence of 60 to 80 percent of consistency is denoted with " + " and evidence of $80+$ percent with “++/--" in Figure 3. For instance, 34 out of 40 cases empirically studied positive relationships between perceived benefits and ITO decision implied $80+$ consistency rate which is depicted in Figure 3 with " ++ ". More discussion on findings is provided in the following.

\section{ITO STRATEGIES}

The $R Q 3$ is related to ITO strategies in the recent literature. Vast and varied ITO strategies such as cloud computing (CC), IS development outsourcing, BPO, ASP, and offshore outsourcing are proposed and applied throughout organizations in the recent years. A brief definition of each outsourcing option included in the reviewed research is provided below:

1. Cloud computing is a shared computing technology where software and hardware are delivered as a service through the real-time network, including Software as a Service (SaaS), platform as a Service (PaaS), and Infrastructure as a Service (IaaS) (Abdel-Basset, Mohamed, \& Chang, 2018; Y. C. Lee, 2019);

2. IT operations and maintenance outsourcing as a general term is defined as the significant contribution made by external vendors in the physical and/or human resources associated with the entire or specific components of the IT infrastructure (i.e., designing, implementing and maintaining hardware, software, and network components) in the client organization (Chakrabarty, 2011);

Figure 3. Conceptual model of the major determinants of ITO decision

\begin{tabular}{|c|c|}
\hline $\begin{array}{l}\text { Technology factors } \\
\text { - Perceived benefits (++) } \\
\text { - Perceived risks (-) } \\
\text { - Perceived complexity (-) } \\
\text { - Perceived security }(+) \\
\text { - Consistency }(+) \\
\text { - Asset specificity (+) } \\
\text { - Service strategic nature }(0) \\
\text { - Perceived cost }(-)\end{array}$ & $\begin{array}{l}\text { Organizational factors } \\
\text { - Availability of required skills and } \\
\text { competencies }(+) \\
\text { - Trust }(++) \\
\text { - Size }(0) \\
\text { - Client prior outsourcing experience }(++) \\
\text { - Positive attitude towards outsourcing }(++) \\
\text { - Top management support }(++) \\
\text { - Requirements specifiability }(++)\end{array}$ \\
\hline $\begin{array}{l}\text { Environmental factors } \\
\text { - Competitive pressures (+) } \\
\text { Regulations and government policies (+) } \\
\text { - Social effects }(++) \\
\text { - Cultural distance among partners (-) }\end{array}$ & $\begin{array}{l}\text { User factors } \\
\text { - Perceived ease of use }(++)\end{array}$ \\
\hline
\end{tabular}

++ More than 80 percent of the evidenceis significantly positive

+60 to 80 percent of the evidence is significantly positive

- More than 80 percent of the evidence is significantly negative

- 60 to 80 percent of the evidence is significantly positive

060 to 80 percent of the evidence implies no positive/negative effect 
3. IS development outsourcing is outsourcing software development tasks including but not limited to designing, analyzing, developing, testing, implementing and maintaining the software product (Chou et al., 2006; Watjatrakul, 2005);

4. BPO refers to an outsourcing relationship where a third party provider is responsible for performing an entire business function for the client organization (Chakrabarty, 2011);

5. Offshore outsourcing refers to the decision to transfer the provision and management of services to external service providers outside of the client organization's home country and also on cruise ships off territorial waters (Chakrabarty, 2011);

6. ASP is a form of outsourcing where an organization rents generally available packaged software applications and related services (Chakrabarty, 2011);

7. Micro-sourcing is an emerging outsourcing practice which hands over small, discrete business functions or applications to many small service providers (B. Lu, Hirschheim, \& Schwarz, 2015).

Based on the results depicted in Figure 4, the number of ITO decision publications in each year has increased from 2001 to 2011, but the trend is diminished after that till the end of 2018. During the period, cloud computing (with 39) was the most studied outsourcing strategies.

\section{FUTURE PATHS OF RESEARCH}

The RQ4 is related to ITO decision promising areas for future research. This section addresses this research question which provides valuable academic insights by clearly figuring out future research directions.

The first set of future research propositions is based on of ITO decision literature classification outcomes in this research (in response to RQ1). A set of diverse theories (e.g., TCE, RBV, TOE) have been employed to study the ITO decision. These models do not consider user acceptance issues after outsourcing services, tasks, or processes to an external vendor. However, one of the most important issues in adopting any sort of innovations such as ITO is the user acceptance (Hameed et al., 2012b). Therefore, it is required to incorporate and employ more user-centric theories in ITO studies. Generally, TAM and TRA theories have been deployed in different contexts to study user behavior in IT innovation. However, TAM and TRA are not good enough to investigate user behavior when there are coercive forces to use and accept such as ITO decision. In such situations, Brown et al. (2002) proposed using TPB which makes it feasible to study the factors affecting ITO decision with a more focused view on user adoption and acceptance. Based on the analysis results on the reviewed

Figure 4. ITO strategies studied during the period

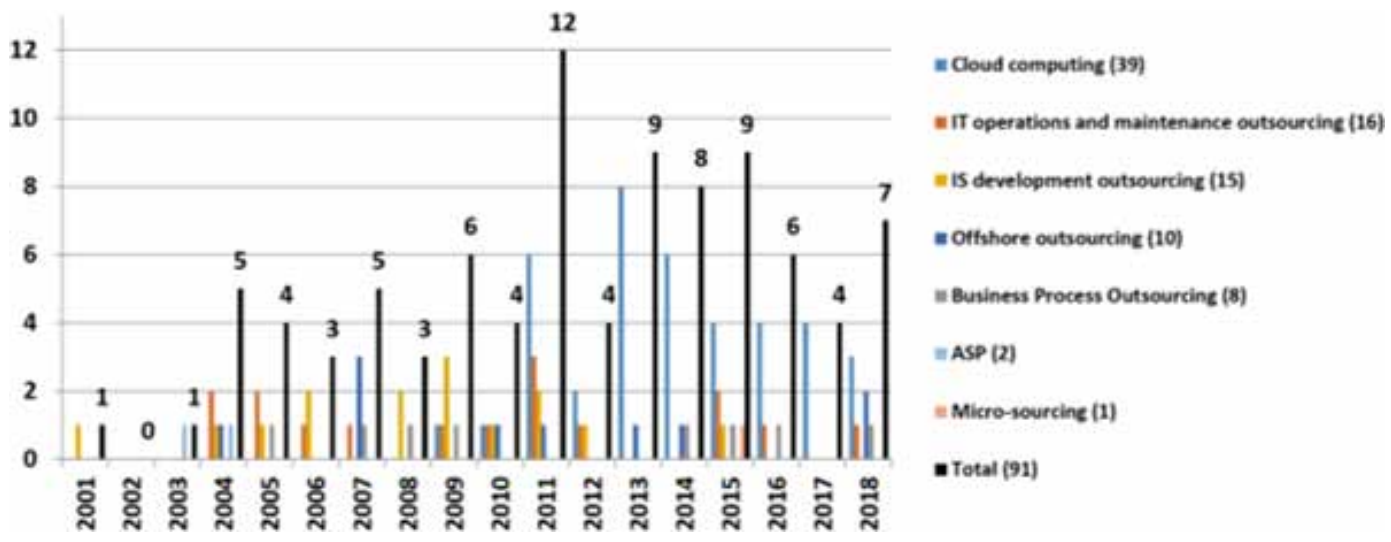


literature with a focus on applied theories, it can be observed that 34 out of 91 reviewed papers did not follow well-defined theoretical foundation (see Appendix II). Out of 57 remaining papers, there is an almost equal split between the number of papers using a single theoretical approach (33) and the number of papers using multiple theoretical perspectives (24). Early research mainly was confined to one theoretical perspective. Over time, the use of two or more theoretical lenses in a single paper became more common (Gerbl, McIvor, \& Humphreys, 2016; Gerbl et al., 2014; Messerschmidt \& Hinz, 2013; Safari, Safari, \& Hasanzadeh, 2015) which might be interpreted as a response to the complex and continually evolving nature of ITO. Additionally, regardless of the theories employed, all the reviewed studies encountered a real limitation concerning using cross-sectional rather than longitudinal datasets. Meanwhile, it is not clear nor widely investigated in the extant literature whether outsourcing level is decreasing, increasing or just somehow fixed during the time or facing different situations. Besides, the effect of ITO strategy, as well as public/private type of the client company, could be of research value. Finally, almost all studies devoted to developed countries (USA, Germany, Taiwan, and England) and there is a research gap in: 1) factors affecting ITO different strategies (e.g., ASP, SaaS, CC) in less developed countries; and 2) comparing the factors affecting ITO decisions in more or less developed contexts.

The second set of future research propositions (in response to RQ2) is based on factors affecting ITO decisions. Regarding the results of the review, user-related factors affecting ITO decisions are mainly viewed from the $\mathrm{CIO}$ or the person responsible for outsourcing viewpoint while other stakeholders such as service/process owners, company owners, CEOs, and people whose careers are impacted and even threatened by outsourcing initiatives, all have considerable impact on ITO decisions. For instance, service/process owners' perceived risks of losing their job position might lead to reduced productivity, or deliberate sabotages. Then, investigating factors affecting on user behavior in ITO decisions with a focus on service/process owners could be future research interests. Furthermore, human resources change management to enhance outsourcing process and reduce deterrent resistance could be followed in future research. Also, a list of factors affecting ITO decisions in four categories is provided in this review, without considering factors' inter-relationships as our review limitation which could be followed in future research. Another future research avenue is considering the concept of IT portfolio outsourcing rather than outsourcing IT services/processes in isolation. Moreover, exploring the reason behind observed inconsistencies in previous research outcomes could be of value for research and practice. Some of the inconsistencies might be influenced by context, client size, or even the selected ITO strategy which should be examined in future research.

The third set of future research propositions (in response to RQ3) is based on ITO strategies. A set of brand-new ITO strategies have been proposed and adopted in practice. Factors affecting such ITO decisions are not well discussed and investigated in the academic literature. For instance, ITIL v3 proposes ITO strategies as in-source, outsource, co-sourcing, multi-sourcing, business process outsourcing, application service provider, knowledge process outsourcing. Also, Chakrabarty (2011) proposed approximately 50 ITO strategies. However, as it is clear from Figure 4, a small set of ITO strategies have been discussed in the extant literature. Meanwhile, investigating factors affecting such new and emerging ITO strategies are proposed in future research. For instance, regarding the social, cultural, legal and political challenges that arise in offshore outsourcing cases (Deng, Mao, \& Wang, 2013; Lacity et al., 2009), investigating and understanding factors affecting such decision would be of great value. To overcome these difficulties and barriers in offshore outsourcing, the concept of near-shore has emerged recently, which considers outsourcing to neighboring countries with similar social and cultural context with cost-saving advantages (Carmel \& Abbott, 2007). As another research stream, there is a paucity of studies that explore the factors affecting knowledge process outsourcing strategy. Such studies would provide considerable business value since knowledge processes such as business analytics are among the main managerial concerns (Lacity, Solomon, et al., 2011). Other strategies such as co-sourcing, multi-vendor (one client, multiple vendors), complex sourcing (many vendors, many clients), spin-offs, and value-added outsourcing based on Chakrabarty 
(2011) terminology and some other sourcing options, including hybrid and plural sourcing (Medina Serrano, González Ramírez, \& Gascó Gascó, 2018), open-sourcing, crowd-sourcing, micro sourcing, and rural sourcing could be of future research interest. Furthermore, following comparative studies about factors affecting different ITO strategies such as ASP, BPO, and KPO could add value to academics as well as practice.

\section{IMPLICATIONS FOR PRACTICE}

For the practitioners, this research provides a deeper understanding of the determinants of ITO decision which somehow refers to the attributes of client firms that should be considered when pursuing ITO initiatives. Especially, the efforts to respond RQ2 and the proposed conceptual model in Figure 3 provide insights for ITO practitioners. The figure depicts the most robust ITO determinants in four technological, organizational, environmental and user categories. Both ITO clients and vendors should focus on these consistent findings for either making ITO decisions or entering ITO relationships. For instance, clients should focus on increasing their ITO benefits while reducing the ITO complexity, cost, and risks. Simultaneously, vendors should provide their services with a focus on long-term mutual benefits with minimum risks for both sides. As another practitioner point, contradicting some previous research (e.g., Benlian et al., 2009; Tiwana \& Bush, 2007) which suggested firms should keep their core or strategic services, in-house, our review implied that there is no robust and consistent support for this argument and firms can outsource their peripheral as well as core services to market vendors. Among other factors should be considered by practitioners is the technological readiness of the client firm which exhibited no influence on ITO decision. Meanwhile, firms are not required to establish technological platforms before ITO, but instead, they should focus on locating and empowering skilled human resources for writing more clear contracts and for managing and monitoring ITO relations. This could finally decrease the potential of vendors' opportunistic behaviors due to the ambiguities in the contracts (Hanafizadeh \& Zare Ravasan, 2017). Also, given the strong influence of mutual trust in ITO relationships, service providers need to pay sufficient attention to make strong and trustworthy relationships with client firms. Furthermore, client firms should attend user interests which include the concerns of top-level managers, middle-level managers, IT managers, CIOs, and sourcing managers in ITO initiatives which can help diminishing negative resistance to ITO efforts.

\section{CONCLUSION AND LIMITATIONS}

This paper reviews 91 ITO articles published between 2000 and 2018 in 51 unique journals. Through categorizing reviewed literature in three descriptive, relational, and comparative studies, it implied that the majority of the reviewed literature devoted to relational studies while comparative studies are overlooked in the extant literature. Based on the quantitative results, conducting comparative studies with a more focus on context, service/process type or strategic nature, ITO level, public/ private type of the client company, and ITO strategy are proposed as future research directions. Besides, a set of theories such as TCE, RBV, TOE, Institutional theory, and risk-benefits framework at the organizational level and TAM, TRA, and TPB at the user level were proposed and empirically examined in identified literature and affecting factors based on each theory were extracted. Furthermore, to identify a set of factors affecting ITO decision, four categories are proposed as technological, organizational, environmental, and user factors. Moreover, extracted literature was reviewed based on the ITO strategies and more or less focused ITO strategies were discovered. According to the results, $\mathrm{CC}$ as a brand-new concept followed by ITO as a general term was the most studied ITO strategies during the period.

All research suffers from limitations, and we, therefore, recognize the following limitations of this review. First, it could not be guaranteed that every ITO article published in a refereed journal was found. Second, regarding the scope of our work, the researchers only included ITO decision literature with 
clients' viewpoint. Investigating factors affecting ITO from vendors' standpoints could be suggested as a future research direction. Third, the relationships in the proposed model only captured direct effects, not interactive effects or dynamic interrelationships which could serve as an extension of our work; we suggest additional research in these areas. Fourth, as a threat to the validity of the results, we might have made errors in coding variables or merging some variables based on the similarity of the intrinsic concept and meaning. Also, we have tried to mitigate the risks by parallel codification process with the help of two of the authors and to check the similarities as well as dissimilarities; however, there is no guarantee that the codes or classifications are perfect. 


\section{REFERENCES}

Abdel-Basset, M., Mohamed, M., \& Chang, V. (2018). NMCDA: A framework for evaluating cloud computing services. Future Generation Computer Systems, 86, 12-29. doi:10.1016/j.future.2018.03.014

Alassafi, M. O., Alharthi, A., Walters, R. J., \& Wills, G. B. (2017). A framework for critical security factors that influence the decision of cloud adoption by Saudi government agencies. Telematics and Informatics, 34(7), 996-1010. doi:10.1016/j.tele.2017.04.010

Alharbi, F., Atkins, A., \& Stanier, C. (2016). Understanding the determinants of Cloud Computing adoption in Saudi healthcare organisations. Complex \& Intelligent Systems, 2(3), 155-171. doi:10.1007/s40747-016-0021-9

Alkhater, N., Walters, R., \& Wills, G. (2018). An empirical study of factors influencing cloud adoption among private sector organisations. Telematics and Informatics, 35(1), 38-54. doi:10.1016/j.tele.2017.09.017

Alshamaila, Y., Papagiannidis, S., Li, F., Dwivedi, Y. K., Papazafeiropoulo, A., Ramdani, B., \& Lorenzo, O. et al. (2013). Cloud computing adoption by SMEs in the north east of England A multi-perspective framework. Journal of Enterprise Information Management, 26(3), 250-275. doi:10.1108/17410391311325225

Alsudairi, M., \& Dwivedi, Y. K. (2010). A multi-disciplinary profile of IS/IT outsourcing research. Journal of Enterprise Information Management, 23(2), 215-258. doi:10.1108/17410391021019787

Alvarez-Suescun, E. (2010). Combining transaction cost and resource-based insights to explain IT implementation outsourcing. Information Systems Frontiers, 12(5), 631-645. doi:10.1007/s10796-010-9237-1

Armbrust, M., Fox, A., Griffith, R., Joseph, A. D., Katz, R., Konwinski, A., \& Stoica, I. et al. (2010). A View of Cloud Computing. Communications of the ACM, 53(4), 50-58. doi:10.1145/1721654.1721672

Atkinson, M. A., Bayazit, O., \& Karpak, B. (2015). A case study using the Analytic Hierarchy Process for IT outsourcing decision making. International Journal of Information Systems and Supply Chain Management, 8(1), 60-84. doi:10.4018/ijisscm.2015010104

Aubert, B., Houde, J.-F., Patry, M., \& Rivard, S. (2012). A multi-level investigation of information technology outsourcing. The Journal of Strategic Information Systems, 21(3), 233-244. doi:10.1016/j.jsis.2012.04.004

Aubert, B., Rivard, S., \& Patry, M. (2004). A transaction cost model of IT outsourcing. Information \& Management, 41(7), 921-932. doi:10.1016/j.im.2003.09.001

Baldwin, L. P., Irani, Z., \& Love, P. E. D. (2001). Outsourcing information systems: Drawing lessons from a banking case study. European Journal of Information Systems, 10(1), 15-24. doi:10.1057/palgrave.ejis.3000372

Bano, M., \& Zowghi, D. (2014). A systematic review on the relationship between user involvement and system success. Information and Software Technology, 58, 148-169. doi:10.1016/j.infsof.2014.06.011

Barthélemy, J., \& Geyer, D. (2004). The determinants of total IT outsourcing : An empirical investigation of French and German firms. Journal of Computer Information Systems, 44(3), 91-97.

Barthélemy, J., \& Geyer, D. (2005). An empirical investigation of IT outsourcing versus quasi-outsourcing in France and Germany. Information \& Management, 42(4), 533-542. doi:10.1016/j.im.2004.02.005

Becerra, M., Lunnan, R., \& Huemer, L. (2008). Trustworthiness, risk, and the transfer of tacit and explicit knowledge between alliance partners. Journal of Management Studies, 45(4), 691-713. doi:10.1111/j.14676486.2008.00766.x

Benamati, J., \& Rajkumar, T. M. (2008). An outsourcing acceptance model: An application of TAM to application development outsourcing decisions. Information Resources Management Journal, 21(2), 80-102. doi:10.4018/ irmj.2008040105

Benlian, A., \& Hess, T. (2011). Opportunities and risks of software-as-a-service: Findings from a survey of IT executives. Decision Support Systems, 52(1), 232-246. doi:10.1016/j.dss.2011.07.007

Benlian, A., Hess, T., \& Buxmann, P. (2009). Drivers of SaaS-Adoption - An Empirical Study of Different Application Types. Business \& Information Systems Engineering, 1(5), 357-369. doi:10.1007/s12599-009-0068-X 
Bhatiasevi, V., \& Naglis, M. (2016). Investigating the structural relationship for the determinants of cloud computing adoption in education. Education and Information Technologies, 21(5), 1197-1223. doi:10.1007/ s10639-015-9376-6

Blaskovich, J., \& Mintchik, N. (2011). Accounting executives and IT outsourcing recommendations: An experimental study of the effect of CIO skills and institutional isomorphism. Journal of Information Technology, 26(2), 139-152. doi:10.1057/jit.2010.19

Brender, N., \& Markov, I. (2013). Risk perception and risk management in cloud computing: Results from a case study of Swiss companies. International Journal of Information Management, 33(5), 726-733. doi:10.1016/j. ijinfomgt.2013.05.004

Brown, S. A., Massey, A. P., Montoya-Weiss, M. M., \& Burkman, J. R. (2002). Do I really have to? User acceptance of mandated technology. European Journal of Information Systems, 11(4), 283-295. doi:10.1057/ palgrave.ejis. 3000438

Bush, A., Tiwana, A., \& Tsuji, H. (2008). An empirical investigation of the drivers of software outsourcing decisions in Japanese organizations. Information and Software Technology, 50(6), 499-510. doi:10.1016/j. infsof.2007.08.006

Carmel, E., \& Abbott, P. (2007). Why'nearshore'means that distance matters. Communications of the ACM, 50(10), 40-46. doi:10.1145/1290958.1290959

Chakrabarty, S. (2011). Making sense of the sourcing and shoring maze: various outsourcing and offshoring alternatives. In IT Outsourcing: Concepts, Methodologies, Tools, and Applications (pp. 18-53). Hershey, PA: IGI Global.

Chen, S., \& Lin, N. (January 2017). (2018). The effect of inter- and intra-organizational distances on success of offshored outsourced innovation: A configurational approach. Journal of Business Research. doi:10.1016/j. jbusres.2018.03.023

Chou, T.-C., Chen, J.-R., \& Pan, S. L. (2006). The impacts of social capital on information technology outsourcing decisions: A case study of a Taiwanese high-tech firm. International Journal of Information Management, 26(3), 249-256. doi:10.1016/j.ijinfomgt.2006.02.002

Choudhury, V., \& Sabherwal, R. (2003). Portfolios of control in outsourced software develop- ment projects. Information Systems Research, 14(3), 291-314. doi:10.1287/isre.14.3.291.16563

Chuang, T.-T., Nakatani, K., \& Zhou, D. (2009). An exploratory study of the extent of information technology adoption in SMEs: An application of upper echelon theory. Journal of Enterprise Information Management, 22(1/2), 183-196. doi:10.1108/17410390910932821

Côrte-Real, N., Ruivo, P., Oliveira, T., \& Popovič, A. (2019). Unlocking the drivers of big data analytics value in firms. Journal of Business Research, 97(January), 160-173. doi:10.1016/j.jbusres.2018.12.072

Currie, W. L., Desai, B., \& Khan, N. (2004). Customer evaluation of application services provisioning in five vertical sectors. Journal of Information Technology, 19(1), 39-58. doi:10.1057/palgrave.jit.2000006

Davis, F. D. (1989). Perceived usefulness, perceived ease of use, and user acceptance of information technology. Management Information Systems Quarterly, 13(3), 319-340. doi:10.2307/249008

Deng, C.-P., Mao, J.-Y., \& Wang, G.-S. (2013). An empirical study on the source of vendors' relational performance in offshore information systems outsourcing. International Journal of Information Management, 33(1), 10-19. doi:10.1016/j.ijinfomgt.2012.04.004

Dey, D., Fan, M., \& Zhang, C. (2010). Design and analysis of contracts for software outsourcing. Information Systems Research, 21(1), 93-114. doi:10.1287/isre.1080.0223

Dhar, S., \& Balakrishnan, B. (2006). Risks, benefits, and challenges in global IT outsourcing: Perspectives and practices. Journal of Global Information Management, 14(3), 59-89. doi:10.4018/jgim.2006070104

Diana, M. L. (2009). Exploring information systems outsourcing in US hospital-based health care delivery systems. Health Care Management Science, 12(4), 434-450. doi:10.1007/s10729-009-9100-4 PMID:20058531 
Dias Ferreira, A. M., \& Barbin Laurindo, F. J. (2009). Outsourcing decision-making aspects considered by IT departments in Brazilian companies. International Journal of Production Economics, 122(1), 305-311. doi:10.1016/j.ijpe.2009.06.024

Dibbern, J., Goles, T., Hirschheim, R., \& Jayatilaka, B. (2004). Information Systems Outsourcing: A Survey and Analysis of the Literature. The Data Base for Advances in Information Systems, 35(4), 6-102. doi:10.1145/1035233.1035236

Ellram, L. M., Tate, W. L., \& Billington, C. (2008). Offshore outsourcing of professional services: A transaction cost economics perspective. Journal of Operations Management, 26(2), 148-163. doi:10.1016/j.jom.2007.02.008

Faisal, M. N., \& Raza, S. A. (2016). IT outsourcing intent in academic institutions in GCC countries: An empirical investigation and multi-criteria decision model for vendor selection. Journal of Enterprise Information Management, 29(3), 432-453. doi:10.1108/JEIM-05-2015-0042

Fjermestad, J., \& Saitta, J. A. (2005). A strategic management framework for IT outsourcing: A review of the literature and the development of a success factors model. Journal of Information Technology Case and Application Research, 7(3), 42-60. doi:10.1080/15228053.2005.10856070

Garrison, G., Kim, S., \& Wakefield, R. L. (2012). Success factors for deploying cloud computing. Communications of the ACM, 55(9), 62-68. doi:10.1145/2330667.2330685

Gerbl, M., McIvor, R., \& Humphreys, P. (2016). Making the business process outsourcing decision: Why distance matters. International Journal of Operations \& Production Management, 36(9), 1037-1064. doi:10.1108/ IJOPM-04-2014-0192

Gerbl, M., McIvor, R., Loane, S., \& Humphreys, P. (2014). A multi-theory approach to understanding the business process outsourcing decision. Journal of World Business. doi:10.1016/j.jwb.2014.08.009

Gerbl, M., McIvor, R., Loane, S., \& Humphreys, P. (2015). A multi-theory approach to understanding the business process outsourcing decision. Journal of World Business, 50(3), 505-518. doi:10.1016/j.jwb.2014.08.009

Gewald, H., \& Dibbern, J. (2009). Risks and benefits of business process outsourcing: A study of transaction services in the German banking industry. Information \& Management, 46(4), 249-257. doi:10.1016/j. im.2009.03.002

Gilley, K. M., \& Rasheed, A. (2000). Making more by doing less: An analysis of outsourcing and its effects on firm performance. Journal of Management, 26(4), 763-790. doi:10.1177/014920630002600408

Gonzalez, R., Gasco, J., \& Llopis, J. (2006). Information systems outsourcing: A literature analysis. Information \& Management, 43(7), 821-834. doi:10.1016/j.im.2006.07.002

Gonzalez, R., Gasco, J., \& Llopis, J. (2009). Information Systems Outsourcing Reasons and Risks : An Empirical Study. The International Journal of Social Sciences (Islamabad), 4(3), 180-191.

Gonzalez, R., Gasco, J., \& Llopis, J. (2010). Information systems offshore outsourcing: An exploratory study of motivations and risks in large Spanish firms. Information Systems Management, 27(4), 340-355. doi:10.1080/10580530903455205

Gooris, J., \& Peeters, C. (2014). Home-host country distance in offshore governance choices. Journal of International Management, 20(1), 73-86. doi:10.1016/j.intman.2013.02.002

Graf, M., \& Mudambi, S. M. (2005). The outsourcing of IT-enabled business processes: A conceptual model of the location decision. Journal of International Management, 11(2), 253-268. doi:10.1016/j.intman.2005.03.010

Greenberg, P. S., Greenberg, R. H., \& Antonucci, Y. L. (2008). The role of trust in the governance of business process outsourcing relationships A transaction cost economics approach. Business Process Management Journal, 14(5), 593-608. doi:10.1108/14637150810903011

Gu, V. C., Cao, Q., \& Duan, W. (2012). Unified Modeling Language (UML) IT adoption-A holistic model of organizational capabilities perspective. Decision Support Systems, 54(1), 257-269. doi:10.1016/j.dss.2012.05.034

Guo, Y., \& Liang, C. (2016). Blockchain application and outlook in the banking industry. Financial Innovation; doi:10.1186/s40854-016-0034-9 
Gupta, P., Seetharaman, A., \& Raj, J. R. (2013). The usage and adoption of cloud computing by small and medium businesses. International Journal of Information Management, 33(5), 861-874. doi:10.1016/j. ijinfomgt.2013.07.001

Gutierrez, A., Boukrami, E., \& Lumsden, R. (2015). Technological, organisational and environmental factors influencing managers' decision to adopt cloud computing in the UK. Journal of Enterprise Information Management, 28(6), 788-807. doi:10.1108/JEIM-01-2015-0001

Hall, J. A. (2005). Financial Performance, CEO Compensation, and Large-Scale Information Technology Outsourcing Decisions. Journal of Management Information Systems, 22(1), 193-221. doi:10.1080/07421222 .2003 .11045838

Hameed, M. A., Counsell, S., \& Swift, S. (2012a). A conceptual model for the process of IT innovation adoption in organizations. Journal of Engineering and Technology Management, 29(3), 358-390. doi:10.1016/j. jengtecman.2012.03.007

Hameed, M. A., Counsell, S., \& Swift, S. (2012b). A meta-analysis of relationships between organizational characteristics and IT innovation adoption in organizations. Information \& Management, 49(5), $218-232$. doi:10.1016/j.im.2012.05.002

Hanafizadeh, P., Keating, B. W., \& Khedmatgozar, H. R. (2014). A systematic review of Internet banking adoption. Telematics and Informatics, 31(3), 492-510. doi:10.1016/j.tele.2013.04.003

Hanafizadeh, P., \& Zare Ravasan, A. (2017). An investigation into the factors influencing the outsourcing decision of e-banking services A multi-perspective framework. Journal of Global Operations and Strategic Sourcing, 10(1), 67-89. doi:10.1108/JGOSS-05-2016-0016

Hanafizadeh, P., \& Zare Ravasan, A. (2018a). A model for selecting IT outsourcing strategy: The case of e-banking channels. Journal of Global Information Technology Management, 21(2), 111-138. doi:10.1080/10 97198X.2018.1462070

Hanafizadeh, P., \& Zare Ravasan, A. (2018b). An empirical analysis on outsourcing decision: The case of e-banking services. Journal of Enterprise Information Management, 31(1), 146-172. doi:10.1108/JEIM-112016-0182

Hätönen, J., \& Eriksson, T. (2009). 30+ years of research and practice of outsourcing - Exploring the past and anticipating the future. Journal of International Management, 15(2), 142-155. doi:10.1016/j.intman.2008.07.002

Hofmann, P., \& Woods, D. (2010). Cloud computing: The limits of public clouds for business applications. IEEE Internet Computing, 14(6), 90-93. doi:10.1109/MIC.2010.136

Hsu, P.-F., Ray, S., \& Li-Hsieh, Y.-Y. (2014). Examining cloud computing adoption intention, pricing mechanism, and deployment model. International Journal of Information Management, 34(4), 474-488. doi:10.1016/j. ijinfomgt.2014.04.006

Huong, N. T., Katsuhiro, U., \& Chi, D. H. (2011). Knowledge Transfer in Offshore Outsourcing. Journal of Global Information Management, 19(2), 27-44. doi:10.4018/jgim.2011040102

Irvine, U. C., Zhu, K., Kraemer, K. L., Gurbaxani, V., \& Xu, S. X. (2006). Migration to open-standard interorganizational systems: Network effects, switching costs, and path dependency. Management Information Systems Quarterly, 30, 515-539. doi:10.2307/25148771

Jain, R. K., \& Natarajan, R. (2011). Factors influencing the outsourcing decisions: A study of the banking sector in India. Strategic Outsourcing, 4(3), 294-322. doi:10.1108/17538291111185485

Jayatilaka, B., Schwarz, A., \& Hirschheim, R. (2003). Determinants of ASP Choice : An Integrated Perspective. European Journal of Information Systems, 12(3), 210-224. doi:10.1057/palgrave.ejis.3000466

Karunagaran, S., Mathew, S. K., \& Lehner, F. (2017). Differential cloud adoption: A comparative case study of large enterprises and SMEs in Germany. Information Systems Frontiers, 1-15. doi:10.1007/s10796-017-9781-z

Kauffman, R. J., Ma, D., \& Yu, M. (2018). A metrics suite of cloud computing adoption readiness. Electronic Markets, 28(1), 11-37. doi:10.1007/s12525-015-0213-y 
Kedia, B. L., \& Lahiri, S. (2007). International outsourcing of services: A partnership model. Journal of International Management, 13(1), 22-37. doi:10.1016/j.intman.2006.09.006

Khalfan, A. M. (2004). Information security considerations in IS/IT outsourcing projects: A descriptive case study of two sectors. International Journal of Information Management, 24(1), 29-42. doi:10.1016/j. ijinfomgt.2003.12.001

Kim, Y. J., Lee, J. M., Koo, C., \& Nam, K. (2013). The role of governance effectiveness in explaining IT outsourcing performance. International Journal of Information Management, 33(5), 850-860. doi:10.1016/j. ijinfomgt.2013.07.003

Kivijärvi, H., \& Toikkanen, J. (2015). Measuring the business value of IT outsourcing: A systems approach. Strategic Outsourcing, 8(2-3), 156-179. doi:10.1108/SO-03-2015-0010

Koong, K. S., Liu, L. C., \& Wang, Y. J. (2007). Taxonomy development and assessment of global information technology outsourcing decisions. Industrial Management \& Data Systems, 107(3), 397-414. doi:10.1108/02635570710734299

Kshetri, N. (2007). Institutional factors affecting offshore business process and information technology outsourcing. Journal of International Management, 13(1), 38-56. doi:10.1016/j.intman.2006.05.003

Lacity, M. C. (2018). Growing Business Interest in Blockchain Technology. MIS Quarterly Executive, 12(September), 201-222. Retrieved from https://angel.co/blockchains

Lacity, M. C., Khan, S., \& Willcocks, L. P. (2009). A review of the IT outsourcing literature: Insights for practice. The Journal of Strategic Information Systems, 18(3), 130-146. doi:10.1016/j.jsis.2009.06.002

Lacity, M. C., Khan, S., Yan, A., \& Willcocks, L. P. (2010). A review of the IT outsourcing empirical literature and future research directions. Journal of Information Technology, 25(4), 395-433. doi:10.1057/jit.2010.21

Lacity, M. C., Khan, S. A., \& Yan, A. (2016). Review of the empirical business services sourcing literature: An update and future directions. Journal of Information Technology, 31(3), 269-328. doi:10.1057/jit.2016.2

Lacity, M. C., Solomon, S., Yan, A., \& Willcocks, L. P. (2011). Business process outsourcing studies: A critical review and research directions. Journal of Information Technology, 26(4), 221-258. doi:10.1057/jit.2011.25

Lacity, M. C., \& Willcocks, L. (2014). Business process outsourcing and dynamic innovation. Strategic Outsourcing, 7(1), 66-92. doi:10.1108/SO-11-2013-0023

Lacity, M. C., \& Willcocks, L. P. (2000). Survey of IT Outsourcing Experiences in US and UK Organizations. Journal of Global Information Management, 8(2), 5-23. doi:10.4018/jgim.2000040101

Lacity, M. C., Willcocks, L. P., \& Khan, S. (2011). Beyond Transaction Cost Economics: Towards an endogenous theory of Information Technology Outsourcing. The Journal of Strategic Information Systems, 20(2), 139-157. doi:10.1016/j.jsis.2011.04.002

Lee, G., \& Xia, W. (2006). Organizational size and IT innovation adoption: A meta-analysis. Information \& Management, 43(8), 975-985. doi:10.1016/j.im.2006.09.003

Lee, M. K. O., \& Cheung, C. M. K. (2004). Internet retailing adoption by small-to-medium sized enterprises (SMEs): A multiple-case study. Information Systems Frontiers, 6(4), 385-397. doi:10.1023/B:ISFI.0000046379.58029.54

Lee, S.-G., Chae, S. H., \& Cho, K. M. (2013). Drivers and inhibitors of SaaS adoption in Korea. International Journal of Information Management, 33(3), 429-440. doi:10.1016/j.jinfomgt.2013.01.006

Lee, Y. C. (2019). Adoption Intention of Cloud Computing at the Firm Level. Journal of Computer Information Systems, 59(1), 61-72. doi:10.1080/08874417.2017.1295792

Lian, J.-W., Yen, D. C., \& Wang, Y.-T. (2014). An exploratory study to understand the critical factors affecting the decision to adopt cloud computing in Taiwan hospital. International Journal of Information Management, 34(1), 28-36. doi:10.1016/j.ijinfomgt.2013.09.004

Liang, H., Wang, J. J., Xue, Y., \& Cui, X. (2016). IT outsourcing research from 1992 to 2013: A literature review based on main path analysis. Information \& Management, 53(2), 227-251. doi:10.1016/j.im.2015.10.001 
Lin, A., \& Chen, N. (2013). Cloud computing as an innovation: Percepetion, attitude, and adoption. International Journal of Information Management, 32(6), 533-540. doi:10.1016/j.ijinfomgt.2012.04.001

Loebbecke, C., \& Huyskens, C. (2006). What drives netsourcing decisions? An empirical analysis. European Journal of Information Systems, 15(4), 415-423. doi:10.1057/palgrave.ejis.3000621

Lorence, D. P., \& Spink, A. (2004). Healthcare information systems outsourcing. International Journal of Information Management, 24(2), 131-145. doi:10.1016/j.ijinfomgt.2003.12.011

Loukis, E., Arvanitis, S., \& Kyriakou, N. (2017). An empirical investigation of the effects of firm characteristics on the propensity to adopt cloud computing. Information Systems and e-Business Management, 15(4), 963-988. doi:10.1007/s10257-017-0338-y

Low, C., Chen, Y., \& Wu, M. (2011). Understanding the determinants of cloud computing adoption. Industrial Management \& Data Systems, 111(7), 1006-1023. doi:10.1108/02635571111161262

Lu, B., Hirschheim, R., \& Schwarz, A. (2015). Examining the antecedent factors of online microsourcing. Information Systems Frontiers, 17(3), 601-617. doi:10.1007/s10796-013-9440-y

Lu, M.-T., Lin, S.-W., \& Tzeng, G.-H. (2013). Improving RFID adoption in Taiwan's healthcare industry based on a DEMATEL technique with a hybrid MCDM model. Decision Support Systems, 56, 259-269. doi:10.1016/j. dss.2013.06.006

Luo, Y., Wang, S. L., Jayaraman, V., \& Zheng, Q. (2013). Governing business process offshoring: Properties, processes, and preferred modes. Journal of World Business, 48(3), 407-419. doi:10.1016/j.jwb.2012.07.024

Mahnke, V., Overby, M. L., \& Vang, J. (2005). Strategic outsourcing of IT services: Theoretical stocktaking and empirical challenges. Industry and Innovation, 12(2), 205-253. doi:10.1080/13662710500087958

Martens, B., \& Teuteberg, F. (2012). Decision-making in cloud computing environments: A cost and risk based approach. Information Systems Frontiers, 14(4), 871-893. doi:10.1007/s10796-011-9317-x

Martins, R., Oliveira, T., \& Thomas, M. A. (2015). Assessing Organizational Adoption of Information Systems Outsourcing. Journal of Organizational Computing and Electronic Commerce, 25(4), 360-378. doi:10.1080/ 10919392.2015.1087702

Matsuno, S., Ito, T., \& Xia, Z. (2009). Determinants of information systems outsourcing : An empirical investigation in Japan. Artificial Life and Robotics, 14(3), 337-341. doi:10.1007/s10015-009-0677-y

Medina Serrano, R., González Ramírez, M. R., \& Gascó Gascó, J. L. (2018). Should we make or buy? An update and review. European Research on Management and Business Economics, 24(3), 137-148. doi:10.1016/j. iedeen.2018.05.004

Messerschmidt, C. M., \& Hinz, O. (2013). Explaining the adoption of grid computing: An integrated institutional theory and organizational capability approach. The Journal of Strategic Information Systems, 22(2), $137-156$. doi:10.1016/j.jsis.2012.10.005

Miranda, S. M., \& Kim, Y. (2006). Professional versus political contexts: Institutional mitigation and the transaction cost heuristic in information systems outsourcing. Management Information Systems Quarterly, 30(3), 725-753. doi:10.2307/25148747

Mohammed, D. (2011). Security in Cloud Computing: An Analysis of Key Drivers and Constraints. Information Security Journal: A Global Perspective, 20(3), 123-127. doi:10.1080/19393555.2010.544704

Moon, Y., Yao, T., \& Jiang, B. (2011). Outsourcing versus joint venture from vendor's perspective. International Journal of Production Economics, 129(1), 23-31. doi:10.1016/j.ijpe.2010.08.006

Mukherjee, D. (2018). Hidden Costs of Offshore Outsourcing: An Analysis of Offshoring Decisions. Journal of Industry, Competition and Trade, 18(3), 303-318. doi:10.1007/s10842-017-0259-y

Oliveira, T., Thomas, M., \& Espadanal, M. (2014). Assessing the determinants of cloud computing adoption: An analysis of the manufacturing and services sectors. Information \& Management, 51(5), 497-510. doi:10.1016/j.im.2014.03.006

Palvia, S. C. J., \& Palvia, P. (2017). Critical Issues Facing IT Outsourcing Vendors in India. In Global Sourcing Of Services: Strategies, Issues and Challenges (pp. 261-300). World Scientific. doi:10.1142/9789813109315_0007 
Park, S. C., \& Ryoo, S. Y. (2013). An empirical investigation of end-users' switching toward cloud computing: A two factor theory perspective. Computers in Human Behavior, 29(1), 160-170. doi:10.1016/j.chb.2012.07.032

Poppo, L., \& Zenger, T. (2002). Do formal contracts and relational governance function as substitutes or complements? Strategic Management Journal, 23(8), 707-725. doi:10.1002/smj.249

Qu, W. G., \& Pinsonneault, A. (2011). Country Environments and the Adoption of IT Outsourcing. Journal of Global Information Management, 19(1), 30-50. doi:10.4018/jgim.2011010102

Rajaeian, M. M., Cater-Steel, A., \& Lane, M. (2017). A systematic literature review and critical assessment of modeldriven decision support for IT outsourcing. Decision Support Systems, 102, 42-56. doi:10.1016/j.dss.2017.07.002

Ratten, V. (2014). A US-China comparative study of cloud computing adoption behavior. Journal of Entrepreneurship in Emerging Economies, 6(1), 53-71. doi:10.1108/JEEE-07-2013-0019

Raut, R. D., Gardas, B. B., Jha, M. K., \& Priyadarshinee, P. (2017). Examining the critical success factors of cloud computing adoption in the MSMEs by using ISM model. The Journal of High Technology Management Research, 28(2), 125-141. doi:10.1016/j.hitech.2017.10.004

Raut, R. D., Priyadarshinee, P., Gardas, B. B., \& Jha, M. K. (2018). Analyzing the factors influencing cloud computing adoption using three stage hybrid SEM-ANN-ISM (SEANIS) approach. Technological Forecasting and Social Change, 134(July), 98-123. doi:<ALIGNMENT.qj></ALIGNMENT>10.1016/j.techfore.2018.05.020

Rekik, M., Boukadi, K., \& Ben Abdallah, H. (2015). A decision-making method for business process outsourcing to the cloud based on business motivation model and AHP. International Journal of Cloud Computing, 4(1), 47. doi:10.1504/IJCC.2015.067709

Safari, F., Safari, N., \& Hasanzadeh, A. (2015). The adoption of software-as-a-service (SaaS): Ranking the determinants. Journal of Enterprise Information Management, 28(3), 400-422. doi:10.1108/JEIM-02-2014-0017

Schneider, S., \& Sunyaev, A. (2016). Determinant factors of cloud-sourcing decisions: Reflecting on the IT outsourcing literature in the era of cloud computing. Journal of Information Technology, 31(1), 1-31. doi:10.1057/jit.2014.25

Schniederjans, M. J., \& Zuckweiler, K. M. (2004). A quantitative approach to the outsourcing-insourcing decision in an international context. Management Decision, 42(8), 974-986. doi:10.1108/00251740410555461

Stafford, T. F. (2011). Active priming of cultural stereotypes in outsourcing decision making. Journal of Global Information Technology Management, 14(2), 27-47. doi:10.1080/1097198X.2011.10856536

Sultan, N. (2014). Making use of cloud computing for healthcare provision: Opportunities and challenges. International Journal of Information Management, 34(2), 177-184. doi:10.1016/j.ijinfomgt.2013.12.011

Sultan, N. A. (2011). Reaching for the "cloud": How SMEs can manage. International Journal of Information Management, 31(3), 272-278. doi:10.1016/j.jinfomgt.2010.08.001

Tafti, M. (2005). Risks factors associated with offshore IT outsourcing. Industrial Management \& Data Systems, 105(5), 549-560. doi:10.1108/02635570510599940

Tajdini, S., \& Nazari, M. (2012). Is Outsourcing Decision: A Quantitative Approach. International Journal of Business and Management, 7(2), 113-129. doi:10.5539/ijbm.v7n2p113

Tanriverdi, H., Konana, P., \& Ge, L. (2007). The Choice of Sourcing Mechanisms for Business Processes. Information Systems Research, 18(3), 280-299. doi:10.1287/isre.1070.0129

Teo, T. S. H., Lin, S., \& Lai, K. (2009). Adopters and non-adopters of e-procurement in Singapore: An empirical study. Omega, 37(5), 972-987. doi:10.1016/j.omega.2008.11.001

Tiwana, A., \& Bush, A. (2007). A Comparison of Transaction Cost, Agency, and Knowledge-Based Predictors of IT Outsourcing Decisions: A U.S.-Japan Cross-Cultural Field Study. Journal of Management Information Systems, 24(1), 259-300. doi:10.2753/MIS0742-1222240108

Tjader, Y. C., Shang, J. S., \& Vargas, L. G. (2010). Offshore outsourcing decision making: A policy-maker's perspective. European Journal of Operational Research, 207(1), 434-444. doi:10.1016/j.ejor.2010.03.042

Tornatzky, L. G., Fleischer, M., \& Chakrabarti, A. K. (1990). The processes of technological innovation (Vol. 273). MA: Lexington Books Lexington. 
van de Weerd, I., Mangula, I. S., \& Brinkkemper, S. (2016). Adoption of software as a service in Indonesia: Examining the influence of organizational factors. Information \& Management, 53(7), 915-928. doi:10.1016/j.im.2016.05.008

Venkatesh, V. (2000). Determinants of perceived ease of use: Integrating control, intrinsic motivation, and emotion into the technology acceptance model. Information Systems Research, 11(4), 342-365. doi:10.1287/ isre.11.4.342.11872

Venkatesh, V., \& Bala, H. (2008). Technology acceptance model 3 and a research agenda on interventions. Decision Sciences, 39(2), 273-315. doi:10.1111/j.1540-5915.2008.00192.x

Venkatesh, V., Morris, M. G., Davis, G. B., \& Davis, F. D. (2003). User acceptance of information technology: Toward a unified view. Management Information Systems Quarterly, 27(3), 425-478. doi:10.2307/30036540

Vivek, S. D., Richey, R. G. Jr, \& Dalela, V. (2009). A longitudinal examination of partnership governance in offshoring: A moving target. Journal of World Business, 44(1), 16-30. doi:10.1016/j.jwb.2008.03.017

Wang, F.-K., \& He, W. (2014). Service strategies of small cloud service providers: A case study of a small cloud service provider and its clients in Taiwan. International Journal of Information Management, 34(3), 406-415. doi:10.1016/j.ijinfomgt.2014.01.007

Watjatrakul, B. (2005). Determinants of IS sourcing decisions: A comparative study of transaction cost theory versus the resource-based view. The Journal of Strategic Information Systems, 14(4), 389-415. doi:10.1016/j.jsis.2005.05.001

Westphal, P., \& Sohal, A. (2016). Outsourcing decision-making: Does the process matter? Production Planning and Control, 27(11), 894-908. doi:10.1080/09537287.2016.1159350

Whitten, D., Chakrabarty, S., \& Wakefield, R. (2010). The strategic choice to continue outsourcing, switch vendors, or backsource: Do switching costs matter? Information \& Management, 47(3), 167-175. doi:10.1016/j.im.2010.01.006

Williams, C., \& Durst, S. (November 2016). (2018). Exploring the transition phase in offshore outsourcing: Decision making amidst knowledge at risk. Journal of Business Research. doi:10.1016/j.jbusres.2018.01.013

Wu, J., Ding, F., Xu, M., Mo, Z., \& Jin, A. (2016). Investigating the Determinants of Decision-Making on Adoption of Public Cloud Computing in E-government. Journal of Global Information Management, 24(3), 71-89. doi:10.4018/JGIM.2016070104

Wu, W.-W. (2011a). Developing an explorative model for SaaS adoption. Expert Systems with Applications, 38(12), 15057-15064. doi:10.1016/j.eswa.2011.05.039

Wu, W.-W. (2011b). Mining significant factors affecting the adoption of SaaS using the rough set approach. Journal of Systems and Software, 84(3), 435-441. doi:10.1016/j.jss.2010.11.890

Wu, W.-W., Lan, L. W., \& Lee, Y.-T. (2011). Exploring decisive factors affecting an organization's SaaS adoption: A case study. International Journal of Information Management, 31(6), 556-563. doi:10.1016/j. ijinfomgt.2011.02.007

Wu, Y., Cegielski, C. G., Hazen, B. T., \& Hall, D. J. (2013). Cloud computing in support of supply chain information system infrastructure: Understanding when to go to the cloud. The Journal of Supply Chain Management, 49(3), 25-41. doi:10.1111/j.1745-493x.2012.03287.x

Yang, D.-H., Kim, S., Nam, C., \& Min, J.-W. (2007). Developing a decision model for business process outsourcing. Computers \& Operations Research, 34(12), 3769-3778. doi:10.1016/j.cor.2006.01.012

Yang, Z., Sun, J., Zhang, Y., \& Wang, Y. (2015). Understanding SaaS adoption from the perspective of organizational users: A tripod readiness model. Computers in Human Behavior, 45, 254-264. doi:10.1016/j.chb.2014.12.022

Zare Ravasan, A., Hanafizadeh, P., Olfat, L., \& Taghavifard, M. T. (2017). A Fuzzy TOPSIS Method for Selecting An E-banking Outsourcing Strategy. International Journal of Enterprise Information Systems, 13(2), 34-49. doi:10.4018/IJEIS.2017040103

Zhang, Y., Liu, S., Tan, J., Jiang, G., \& Zhu, Q. (2018). Effects of risks on the performance of business process outsourcing projects: The moderating roles of knowledge management capabilities. International Journal of Project Management, 36(4), 627-639. doi:10.1016/j.ijproman.2018.02.002 


\section{APPENDIX I}

T01 - Perceived benefits: Perceived benefits can be divided into two main sections: tangible and intangible. ITO Tangible benefits are those directly related to gain dollar figure in organizations such as time savings, cost savings, ROI, and so forth. Intangible benefits are difficult or sometimes impossible to quantify which include a focus on core competencies, access to specialized resources, quality improvements and so on (Guo \& Liang, 2016; Lacity \& Willcocks, 2014).

T02 - Perceived risks: The extent to which ITO exposes a client to a chance of loss or damage (Kivijärvi \& Toikkanen, 2015; Liang et al., 2016).

T03 - Performance assessment and control issues: The degree of difficulty in measuring performance of exchange partners in circumstances of joint effort, soft outcomes, and ambiguous links between effort and performance (Alvarez-Suescun, 2010; Diana, 2009).

T04 - Perceived complexity: The extent to which the ITO is sophisticated and difficult to standardize, requiring a great deal of specialized knowledge to undertake the task (Lin \& Chen, 2013).

T05 - Perceived security: The degree to which information security encompasses three main security aspects (Integrity: gathering and retaining accurate information and avoiding malicious modification; Availability: providing access to the information when and where desired; and Confidentiality: avoiding disclosure to unauthorized or unwanted persons) is preserved by a client (Khalfan, 2004).

T06 - Consistency: The degree to which ITO is perceived as consistent with the existing values, strategies, legacy systems, and needs of potential adopters (Alshamaila et al., 2013).

T07 - Asset specificity: The degree to which an asset can be redeployed to alternative uses and by alternative users without sacrifice of productive value (Ellram et al., 2008).

T08 - Service strategic nature: The degree to which a service represents the client's primary competency in creating value for the customer (Gilley \& Rasheed, 2000).

T09 - Perceived cost: The perceived costs of searching, creating, negotiating, monitoring, and administrating an ITO contract between the client and its service providers (Teo et al., 2009).

T10 - Data protection issues: Data protection requires the information of where personal data is located, by whom it is processed and who is responsible for data processing (Karunagaran, Mathew, \& Lehner, 2017).

T11 - Perceived privacy: The client's perception of information being improperly obtained and used by service providers (Ratten, 2014).

T12 - Integration issues: Technological issues surrounding the integration of outsourced service/ system and legacy systems (S.-G. Lee et al., 2013).

T13 - Trialability: The degree to which ITO may be experimented with on a limited basis (Alshamaila et al., 2013).

T14 - Lack of proper and in place standards: Lack of appropriate SLA standards, legal standards regarding compensation and responsibility and so on (S.-G. Lee et al., 2013).

T15 - Transaction frequency: The number of times a client organization initiates a transaction, typically categorized as either occasional or frequent (Lacity et al., 2016).

T16 - Service/ Process complexity: The degree to which a process is difficult to understand or carry out (Y. Wu et al., 2013).

T17 - Business process IT detachability: The extent to which the process and its underlying IT infrastructure are loosely coupled to allow separation, independent execution of the process on another IT infrastructure, and recombination without loss of functionality (Tanriverdi, Konana, $\& \mathrm{Ge}, 2007)$.

T18 - Business process modularity: The extent to which a business process is loosely coupled, mature, and standardized enough to be separated from a firm's other business processes, executed independently, and recombined without loss of functionality (Tanriverdi et al., 2007). 
O01 - Availability of required skills and competencies: The extent to which required skills and competencies (money, managerial, technical, contractual) be available in the client organization to outsource IT services (Gerbl et al., 2014; Koong et al., 2007; Lian et al., 2014).

002 - Trust: The client's expectation that the service provider will perform as expected and treat the client firm fairly and reasonably (Garrison, Kim, \& Wakefield, 2012).

003 - Size: The size of a business is the organization's resources, transaction volumes, or workforce size (G. Lee \& Xia, 2006).

004 - Client prior outsourcing experience: The extent to which a client is familiar with outsourcing strategies and has past positive experiences (Benamati \& Rajkumar, 2008).

O05 - Positive attitude towards ITO: The overall evaluative appraisal of a decision maker toward ITO (Benlian et al., 2009).

006 - Top management support: The extent to which the executives understand the nature of ITO and therefore fully support it (Lian et al., 2014).

007 - Organizational knowledge level: Technical skills and knowledge of the client's technical staff in the outsourced project's domain (Tiwana \& Bush, 2007).

O08 - IT department size: Number of IT employees (Hsu et al., 2014).

009 - Technological readiness (IT infrastructure): Refers to the technological infrastructure and IT human resources (Low et al., 2011).

010 - Requirements specifiability: Ease with which project requirements can be wholly and accurately conveyed to a vendor at the beginning of the project through a formal project specifications document (Tiwana \& Bush, 2007).

011 - Top management/organizational innovativeness: The extent to which the top management/ organization readily accept and conform to an innovative technology (Lian et al., 2014).

012 - IT department budget: Annual budget for IT department as a percent of a firm's total budget (Hsu et al., 2014).

013 - Bounded rationality of organization: The extent to which the internal organizational actors are boundedly rational which limits their ability to ultimately anticipate eventualities, thereby constraining decision makers' ability to thoroughly stipulate contract terms (Miranda \& Kim, 2006).

014 - Lack of qualified employees to do the tasks in-house: The extent to which a firm has qualified employees to do the tasks in-house instead of outsourcing them (Messerschmidt \& Hinz, 2013).

015 - IT budget development: The rate of IT-budget development in the next two years (Messerschmidt \& Hinz, 2013).

016 - Internal resistance to ITO: The extent to which a firm is resistant to ITO (S.-G. Lee et al., 2013).

O17 - Obligations for ITO: commitment or duty for ITO in the future (Chou et al., 2006).

018 - Poor firm-level financial performance: The financial performance of a firm regarding indexes such as operating expenses, short-term cash needs, financial leverages and so on (Hall, 2005).

019 - CEO compensation: CEO incentives such as annual bonuses, stock options, stock grants, and long-term incentive payouts (Hall, 2005).

O20 - CIO skills: Relates to CIO's IT and ITO skills (Hall, 2005).

021 - Knowledge loss: The potential for losing the Know-How knowledge and doing services inhouse in the future (Gerbl, McIvor, Loane, \& Humphreys, 2015).

022 - Management style: It is a perception which narrates to the overview of new management practices, processes, or structures projected to further organizational goals (Raut, Priyadarshinee, Gardas, \& Jha, 2018).

023 - Vendor management capacity: Risk with managing cloud services relationships that require contractual governance (Kauffman, Ma, \& Yu, 2018).

024 - Business level strategy: Using the differentiation strategy vs cost-leadership strategy (Hanafizadeh \& Zare Ravasan, 2018a). 
025 - Industry type: The sector to which the business belongs (Alshamaila et al., 2013).

E01 - Competitive pressures: The extent to which a firm perceives pressure from business competitors that encourage the firm to outsource IT services for the sake of maintaining competitiveness (Irvine, Zhu, Kraemer, Gurbaxani, \& Xu, 2006).

E02 - Regulations and government policies: The extent to which regulations and government policies motivate or limit outsourcing IT services to external vendors (S.-G. Lee et al., 2013; Lian et al., 2014).

E03 - Environmental uncertainty: The extent to which the business requirements of the project are expected to change during development (Bush et al., 2008).

E04 - Social effects: Normative influence of key referent groups, such as peers or co-workers, on ones' behavioral choice (Park \& Ryoo, 2013).

E05 - Cultural distance among partners: The extent to which there is cultural distance among partners concerning employee's values and norms, attitudes towards technology, customers, interpersonal contact and interaction, and overall role perception (Graf \& Mudambi, 2005).

E06 - Partners' pressure: The extent to which a firm perceives pressure from business partners that encourage the firm to outsource IT services (Low et al., 2011).

E07 - Market maturity: The extent of which there are a high number of service providers in the market, providing the firm's required technical and business resources/ skills (Graf \& Mudambi, 2005).

E08 - Social norms: The ITO degree of compatibility with the values and norms (e.g., job creation, protection of the natural environment) (Koong et al., 2007).

E09 - Opportunistic behavior of vendors: The extent to which vendors might show opportunistic behavior, raise prices, reduce service levels, and the like (Miranda \& Kim, 2006).

E10 - Geo-distance between client and vendor: The extent to which the time zone of the ITO location to major markets and company headquarters are close (Graf \& Mudambi, 2005).

E11 - Client-side infrastructures: Required telecommunication infrastructure to support outsourced services in the client side region (Gonzalez, Gasco, \& Llopis, 2010).

E12 - Vendor support: The quality of supplier support activities that can significantly influence the probability that an operation will be outsourced to a vendor (Alshamaila et al., 2013).

E13 - Taxation issues: The extent to which the tax policy of the client country is attractive for the off-shore service provider (Graf \& Mudambi, 2005).

E14 - Investment motives: The extent to which the client country is attractive for the off-shore service provider from the investment motives points of view (Graf \& Mudambi, 2005).

E15 - Vendor power: The extent to which there is a sufficient number of reputable and trustworthy external IT vendors who can potentially provide IT facilities and services to us for the outsourced operation (Diana, 2009).

E16 - Human capital: The availability of required skilled human resources in the destination country or region (Gerbl et al., 2015).

U01 - Perceived ease of use: The extent to which individuals in the client firm perceive ITO easy to understand and adopt (Ratten, 2014).

U02 - Perceived usefulness: The extent to which individuals in the client firm perceive ITO useful in the organization (W.-W. Wu, 2011a).

U03 - User innovation: The degree which individuals in the client firm are open to new information, technology, ITO new approaches (e.g., ASP, SaaS, CC) (Ratten, 2014). 


\section{APPENDIX ||}

Table 9. Master code

\begin{tabular}{|c|c|c|c|c|c|c|c|c|c|c|c|}
\hline Id & Citation & Context & Journal & $\begin{array}{c}\text { Base } \\
\text { Theory* }\end{array}$ & $\begin{array}{c}\text { Outsourcing } \\
\text { Strategy** }\end{array}$ & $\begin{array}{l}\text { Research } \\
\text { Method }\end{array}$ & $\begin{array}{l}\text { Technology } \\
\text { Factors }\end{array}$ & $\begin{array}{c}\text { Organizational } \\
\text { Factors }\end{array}$ & $\begin{array}{c}\text { Environmental } \\
\text { Factors }\end{array}$ & $\begin{array}{l}\text { User } \\
\text { Factors }\end{array}$ & Class*** \\
\hline 1 & $\begin{array}{l}\text { (Baldwin, Irani, } \\
\text { \& Love, 2001) }\end{array}$ & UK & $\begin{array}{l}\text { European } \\
\text { Journal of } \\
\text { Information } \\
\text { Systems }\end{array}$ & - & ISDO & Case study & T01 & $\mathrm{O} 14$ & E02 & & $\mathrm{D}$ \\
\hline 2 & $\begin{array}{l}\text { (Jayatilaka et } \\
\text { al., 2003) }\end{array}$ & USA & $\begin{array}{l}\text { European } \\
\text { Journal of } \\
\text { Information } \\
\text { Systems }\end{array}$ & $\begin{array}{l}\text { TCE, RBV, } \\
\text { RDT, KBP }\end{array}$ & ASP & Survey & $\begin{array}{l}\text { T01, T02, } \\
\text { T05, T06, } \\
\text { T12 }\end{array}$ & $\mathrm{O} 01, \mathrm{O} 07$ & E01 & & $\mathrm{D}$ \\
\hline 3 & $\begin{array}{l}\text { (Currie, Desai, } \\
\text { \& Khan, 2004) }\end{array}$ & UK & $\begin{array}{l}\text { Journal of } \\
\text { Information } \\
\text { Technology }\end{array}$ & - & ASP & Survey & $\begin{array}{l}\text { T01, T02, } \\
\text { T05 }\end{array}$ & & & & $\mathrm{D}$ \\
\hline 4 & $\begin{array}{l}\text { (Lorence \& } \\
\text { Spink, 2004) }\end{array}$ & USA & $\begin{array}{l}\text { International } \\
\text { Journal of } \\
\text { Information } \\
\text { Management }\end{array}$ & - & ISDO & Survey & T01 & & E02 & & $\mathrm{D}$ \\
\hline 5 & $\begin{array}{l}\text { (Aubert et al., } \\
\text { 2004) }\end{array}$ & Canada & $\begin{array}{l}\text { Information \& } \\
\text { Management }\end{array}$ & $\begin{array}{l}\text { TCE, } \\
\text { incomplete } \\
\text { contracts } \\
\text { theories }\end{array}$ & ITOMO & Survey & T03, T07 & 001 & & & $\mathrm{R}$ \\
\hline 6 & $\begin{array}{l}\text { (Barthélemy \& } \\
\text { Geyer, 2004) }\end{array}$ & $\begin{array}{l}\text { Germany/ } \\
\text { France }\end{array}$ & $\begin{array}{l}\text { Journal of } \\
\text { Computer } \\
\text { Information } \\
\text { Systems }\end{array}$ & - & ITOMO & Survey & T01 & $\mathrm{O} 08$ & & & $\mathrm{C}$ \\
\hline 7 & $\begin{array}{l}\text { (Schniederjans } \\
\& \text { Zuckweiler, } \\
\text { 2004) }\end{array}$ & USA & $\begin{array}{l}\text { Management } \\
\text { Decision }\end{array}$ & - & $\begin{array}{l}\text { Offshore } \\
\text { outsourcing }\end{array}$ & Case study & T01, T02 & & E05 & & $\mathrm{R}$ \\
\hline 8 & (Hall, 2005) & USA & $\begin{array}{l}\text { Journal of } \\
\text { Management } \\
\text { Information } \\
\text { Systems }\end{array}$ & - & ITOMO & Survey & & O18, O19 & & & $\mathrm{R}$ \\
\hline 9 & $\begin{array}{l}\text { (Barthélemy \& } \\
\text { Geyer, 2005) }\end{array}$ & $\begin{array}{l}\text { Germany } \\
\text { /France }\end{array}$ & $\begin{array}{l}\text { Information \& } \\
\text { Management }\end{array}$ & TCE & IтOMO & Survey & T07 & $\mathrm{O} 08$ & E04 & & $\mathrm{C}$ \\
\hline 10 & $\begin{array}{l}\text { (Graf \& } \\
\text { Mudambi, } \\
\text { 2005) }\end{array}$ & USA & $\begin{array}{l}\text { Journal of } \\
\text { International } \\
\text { Management }\end{array}$ & $\begin{array}{l}\text { Dunning's } \\
\text { eclectic } \\
\text { theory }\end{array}$ & $\mathrm{BPO}$ & $\begin{array}{l}\text { Conceptual } \\
\text { Model }\end{array}$ & $\begin{array}{l}\text { T01, T02, } \\
\text { T03, T07, } \\
\text { T08 }\end{array}$ & O01, O09 & $\begin{array}{l}\text { E05, E07, E10, } \\
\text { E13, E14 }\end{array}$ & & $\mathrm{R}$ \\
\hline 11 & $\begin{array}{l}\text { (Watjatrakul, } \\
\text { 2005) }\end{array}$ & Thailand & $\begin{array}{l}\text { The Journal } \\
\text { of Strategic } \\
\text { Information } \\
\text { Systems }\end{array}$ & TCE, RBV & ISDO & Case study & T03, T07 & & E03 & & $\mathrm{R}$ \\
\hline 12 & $\begin{array}{l}\text { (Miranda \& } \\
\text { Kim, 2006) }\end{array}$ & USA & MIS Quarterly & $\begin{array}{l}\text { TCE, } \\
\text { Institutional } \\
\text { theory }\end{array}$ & ISDO & Survey & $\begin{array}{l}\text { T03, T07, } \\
\text { T15 }\end{array}$ & $\mathrm{O} 13$ & E03, E09 & & $\mathrm{R}$ \\
\hline 13 & $\begin{array}{l}\text { (Chou et al., } \\
2006 \text { ) }\end{array}$ & Taiwan & $\begin{array}{l}\text { International } \\
\text { Journal of } \\
\text { Information } \\
\text { Management }\end{array}$ & $\begin{array}{l}\text { Social } \\
\text { capital } \\
\text { theory }\end{array}$ & ISDO & Case study & & $\mathrm{O} 02, \mathrm{O} 17$ & & & $\mathrm{R}$ \\
\hline 14 & $\begin{array}{l}\text { (Dhar \& } \\
\text { Balakrishnan, } \\
\text { 2006) }\end{array}$ & $\begin{array}{l}\text { Multi- } \\
\text { national }\end{array}$ & $\begin{array}{l}\text { Journal } \\
\text { of Global } \\
\text { Information } \\
\text { Management }\end{array}$ & RBF, TCE & ITO & Case study & T01, T02 & & & & $\mathrm{D}$ \\
\hline 15 & $\begin{array}{l}\text { (Tanriverdi et } \\
\text { al., 2007) }\end{array}$ & USA & $\begin{array}{l}\text { Information } \\
\text { Systems } \\
\text { Research }\end{array}$ & - & BPO & Survey & $\begin{array}{l}\text { T01, T07, } \\
\text { T08, T17, } \\
\text { T18 }\end{array}$ & O04 & & & $\mathrm{R}$ \\
\hline 16 & $\begin{array}{l}\text { (Kedia \& } \\
\text { Lahiri, 2007) }\end{array}$ & USA & $\begin{array}{l}\text { Journal of } \\
\text { International } \\
\text { Management }\end{array}$ & $\begin{array}{l}\text { TCE, RBV, } \\
\text { RDT }\end{array}$ & $\begin{array}{l}\text { Offshore } \\
\text { outsourcing }\end{array}$ & $\begin{array}{l}\text { Conceptual } \\
\text { Model }\end{array}$ & T01 & $\mathrm{O} 01, \mathrm{O} 02$ & E01, E10 & & $\mathrm{R}$ \\
\hline 17 & $\begin{array}{l}\text { (Koong et al., } \\
\text { 2007) }\end{array}$ & USA & $\begin{array}{l}\text { Industrial } \\
\text { Management \& } \\
\text { Data Systems }\end{array}$ & $\begin{array}{l}\text { TCE, } \\
\text { Agency } \\
\text { theory, } \\
\text { RDT, } \\
\text { Competitive } \\
\text { forces, } \\
\text { TOE }\end{array}$ & $\begin{array}{l}\text { Offshore } \\
\text { outsourcing }\end{array}$ & $\begin{array}{l}\text { Conceptual } \\
\text { Model }\end{array}$ & $\begin{array}{l}\text { T01, T02, } \\
\text { T09 }\end{array}$ & $\mathrm{O} 01$ & $\begin{array}{l}\text { E01, E03, E08, } \\
\text { E15 }\end{array}$ & & $\mathrm{R}$ \\
\hline 18 & (Kshetri, 2007) & USA & $\begin{array}{l}\text { Journal of } \\
\text { International } \\
\text { Management }\end{array}$ & $\begin{array}{l}\text { institutional } \\
\text { theory }\end{array}$ & $\begin{array}{l}\text { Offshore } \\
\text { outsourcing }\end{array}$ & $\begin{array}{l}\text { Conceptual } \\
\text { Model }\end{array}$ & & & E02, E08 & & $\mathrm{R}$ \\
\hline
\end{tabular}


Table 9. Continued

\begin{tabular}{|c|c|c|c|c|c|c|c|c|c|c|c|}
\hline Id & Citation & Context & Journal & $\begin{array}{c}\text { Base } \\
\text { Theory* }\end{array}$ & $\begin{array}{l}\text { Outsourcing } \\
\text { Strategy*** }\end{array}$ & $\begin{array}{l}\text { Research } \\
\text { Method }\end{array}$ & $\begin{array}{l}\text { Technology } \\
\text { Factors }\end{array}$ & $\begin{array}{c}\text { Organizational } \\
\text { Factors }\end{array}$ & $\begin{array}{c}\text { Environmental } \\
\text { Factors }\end{array}$ & $\begin{array}{l}\text { User } \\
\text { Factors }\end{array}$ & Class**** \\
\hline 19 & $\begin{array}{l}\text { (Tiwana \& } \\
\text { Bush, 2007) }\end{array}$ & $\begin{array}{l}\text { Japan/ } \\
\text { USA }\end{array}$ & $\begin{array}{l}\text { Journal of } \\
\text { Management } \\
\text { Information } \\
\text { Systems }\end{array}$ & $\begin{array}{l}\text { TCE, } \\
\text { Agency } \\
\text { theory, } \\
\text { KBP }\end{array}$ & ITOMO & Survey & $\begin{array}{l}\text { T01, T03, } \\
\text { T08, T16 }\end{array}$ & $\mathrm{O} 07, \mathrm{O} 10$ & E03, E09 & & $\mathrm{R}$ \\
\hline 20 & $\begin{array}{l}\text { (Greenberg, } \\
\text { Greenberg, } \\
\text { \& Antonucci, } \\
\text { 2008) }\end{array}$ & USA & $\begin{array}{l}\text { Business Process } \\
\text { Management } \\
\text { Journal }\end{array}$ & TCE & $\mathrm{BPO}$ & $\begin{array}{l}\text { Conceptual } \\
\text { Model }\end{array}$ & $\begin{array}{l}\text { T03, T07, } \\
\text { T15 }\end{array}$ & 013 & E03, E09 & & $\mathrm{R}$ \\
\hline 21 & $\begin{array}{l}\text { (Bush et al., } \\
2008 \text { ) }\end{array}$ & Japan & $\begin{array}{l}\text { Information } \\
\text { and Software } \\
\text { Technology }\end{array}$ & - & ISDO & Survey & $\begin{array}{l}\text { T01, T03, } \\
\text { T04, T08 }\end{array}$ & $\mathrm{O} 01, \mathrm{O} 02, \mathrm{O} 10$ & E03 & & $\mathrm{R}$ \\
\hline 22 & $\begin{array}{l}\text { (Benamati \& } \\
\text { Rajkumar, } \\
\text { 2008) }\end{array}$ & USA & $\begin{array}{l}\text { Information } \\
\text { Resources } \\
\text { Management } \\
\text { Journal }\end{array}$ & TAM & ISDO & Survey & T02 & $\mathrm{O} 04, \mathrm{O} 05$ & E01 & $\begin{array}{l}\text { U01, } \\
\text { U02 }\end{array}$ & $\mathrm{R}$ \\
\hline 23 & $\begin{array}{l}\text { (Benlian et al., } \\
\text { 2009) }\end{array}$ & Germany & $\begin{array}{l}\text { Business \& } \\
\text { Information } \\
\text { Systems } \\
\text { Engineering }\end{array}$ & $\begin{array}{l}\text { RBV, TCE, } \\
\text { TPB }\end{array}$ & $\mathrm{CC}$ & Survey & T08 & O05 & E04 & & $\mathrm{C}$ \\
\hline 24 & (Diana, 2009) & USA & $\begin{array}{l}\text { Health care } \\
\text { management } \\
\text { science }\end{array}$ & TCE, SMT & ISDO & Survey & T03, T07 & & E15 & & $\mathrm{R}$ \\
\hline 25 & $\begin{array}{l}\text { (Gonzalez et al., } \\
\text { 2009) }\end{array}$ & Spain & $\begin{array}{l}\text { International } \\
\text { Journal of Social } \\
\text { Sciences }\end{array}$ & RBF & ISDO & Survey & T01, T02 & & & & $\mathrm{D}$ \\
\hline 26 & $\begin{array}{l}\text { (Dias Ferreira } \\
\text { \& Barbin } \\
\text { Laurindo, } \\
\text { 2009) }\end{array}$ & Brazil & $\begin{array}{l}\text { International } \\
\text { Journal of } \\
\text { Production } \\
\text { Economics }\end{array}$ & - & ITOMO & Survey & T02, T09 & & & & $\mathrm{R}$ \\
\hline 27 & $\begin{array}{l}\text { (Gewald \& } \\
\text { Dibbern, 2009) }\end{array}$ & Germany & $\begin{array}{l}\text { Information \& } \\
\text { Management }\end{array}$ & RBF & $\mathrm{BPO}$ & Survey & T01, T02 & & & & $\mathrm{C}$ \\
\hline 28 & $\begin{array}{l}\text { (Matsuno, Ito, } \\
\text { \& Xia, 2009) }\end{array}$ & Japan & $\begin{array}{l}\text { Artificial Life } \\
\text { and Robotics }\end{array}$ & - & ISDO & Survey & T07 & $\mathrm{O} 03$ & & & $\mathrm{R}$ \\
\hline 29 & $\begin{array}{l}\text { (Gonzalez et al., } \\
2010 \text { ) }\end{array}$ & Spain & $\begin{array}{l}\text { Information } \\
\text { Systems } \\
\text { Management }\end{array}$ & $\begin{array}{l}\text { TCE, RBV, } \\
\text { Innovation } \\
\text { Theories, } \\
\text { RET, } \\
\text { Agency } \\
\text { Theory, } \\
\text { SMT, CSR }\end{array}$ & $\begin{array}{l}\text { Offshore } \\
\text { outsourcing }\end{array}$ & Survey & $\begin{array}{l}\text { T01, T02, } \\
\text { T09 }\end{array}$ & & E04, E05, E11 & & $\mathrm{R}$ \\
\hline 30 & $\begin{array}{l}\text { (Alvarez- } \\
\text { Suescun, 2010) }\end{array}$ & Spain & $\begin{array}{l}\text { Information } \\
\text { Systems } \\
\text { Frontiers }\end{array}$ & TCE, RBV & ITOMO & Survey & $\begin{array}{l}\text { T03, T07, } \\
\text { T08 }\end{array}$ & O04 & & & $\mathrm{R}$ \\
\hline 31 & $\begin{array}{l}\text { (Dey, Fan, \& } \\
\text { Zhang, 2010) }\end{array}$ & $\begin{array}{l}\text { Multi- } \\
\text { national }\end{array}$ & $\begin{array}{l}\text { Information } \\
\text { Systems } \\
\text { Research }\end{array}$ & - & ISDO & Case study & T03 & O07, O10 & & & $\mathrm{D}$ \\
\hline 32 & $\begin{array}{l}\text { (Armbrust et } \\
\text { al., 2010) }\end{array}$ & USA & $\begin{array}{l}\text { Communications } \\
\text { of the ACM }\end{array}$ & - & $\mathrm{CC}$ & $\begin{array}{l}\text { Conceptual } \\
\text { Model }\end{array}$ & $\mathrm{T} 01, \mathrm{~T} 02$ & & & & $\mathrm{D}$ \\
\hline 33 & $\begin{array}{l}\text { (Qu \& } \\
\text { Pinsonneault, } \\
\text { 2011) }\end{array}$ & $\begin{array}{l}\text { Multi- } \\
\text { national }\end{array}$ & $\begin{array}{l}\text { Journal } \\
\text { of Global } \\
\text { Information } \\
\text { Management }\end{array}$ & $\begin{array}{l}\text { Institutional } \\
\text { Economics }\end{array}$ & ITO & Survey & & O02, O09 & E07 & & $\mathrm{R}$ \\
\hline 34 & $\begin{array}{l}\text { (Huong, } \\
\text { Katsuhiro, \& } \\
\text { Chi, 2011) }\end{array}$ & $\begin{array}{l}\text { Japan/ } \\
\text { Vietnam }\end{array}$ & $\begin{array}{l}\text { Journal } \\
\text { of Global } \\
\text { Information } \\
\text { Management }\end{array}$ & - & $\begin{array}{l}\text { Offshore } \\
\text { outsourcing }\end{array}$ & Case study & & & E05, E11 & & D \\
\hline 35 & $\begin{array}{l}\text { (Wu, Lan, \& } \\
\text { Lee, 2011) }\end{array}$ & Taiwan & $\begin{array}{l}\text { International } \\
\text { Journal of } \\
\text { Information } \\
\text { Management }\end{array}$ & RBF & $\mathrm{CC}$ & $\begin{array}{l}\text { Survey } \\
\text { Case } \\
\text { study }\end{array}$ & T01, T02 & & & & $\mathrm{R}$ \\
\hline 36 & $\begin{array}{l}\text { (Blaskovich } \\
\text { \& Mintchik, } \\
\text { 2011) }\end{array}$ & USA & $\begin{array}{l}\text { Journal of } \\
\text { Information } \\
\text { Technology }\end{array}$ & - & ITOMO & Survey & & $\mathrm{O} 20$ & E01 & & C \\
\hline 37 & $\begin{array}{l}\text { (Jain \& } \\
\text { Natarajan, } \\
\text { 2011) }\end{array}$ & India & $\begin{array}{l}\text { Strategic } \\
\text { Outsourcing: } \\
\text { An International } \\
\text { Journal }\end{array}$ & RBF & ITOMO & Survey & T01, T02 & & & & $\mathrm{R}$ \\
\hline
\end{tabular}


Table 9. Continued

\begin{tabular}{|c|c|c|c|c|c|c|c|c|c|c|c|}
\hline Id & Citation & Context & Journal & $\begin{array}{c}\text { Base } \\
\text { Theory* }\end{array}$ & $\begin{array}{l}\text { Outsourcing } \\
\text { Strategy** }\end{array}$ & $\begin{array}{l}\text { Research } \\
\text { Method }\end{array}$ & $\begin{array}{l}\text { Technology } \\
\text { Factors }\end{array}$ & $\begin{array}{c}\text { Organizational } \\
\text { Factors }\end{array}$ & $\begin{array}{c}\text { Environmental } \\
\text { Factors }\end{array}$ & $\begin{array}{l}\text { User } \\
\text { Factors }\end{array}$ & Class*** $^{* *}$ \\
\hline 38 & $\begin{array}{l}\text { (Mohammed, } \\
\text { 2011) }\end{array}$ & USA & $\begin{array}{l}\text { Information } \\
\text { Security Journal: } \\
\text { A Global } \\
\text { Perspective }\end{array}$ & - & $\mathrm{CC}$ & $\begin{array}{l}\text { Conceptual } \\
\text { Model }\end{array}$ & $\begin{array}{l}\text { T01, T05, } \\
\text { T11 }\end{array}$ & $\mathrm{O} 02$ & & & $\mathrm{D}$ \\
\hline 39 & (Stafford, 2011) & $\begin{array}{l}\text { China/ } \\
\text { India }\end{array}$ & $\begin{array}{l}\text { Journal } \\
\text { of Global } \\
\text { Information } \\
\text { Technology } \\
\text { Management }\end{array}$ & - & ISDO & Case study & & & E05 & & $\mathrm{D}$ \\
\hline 40 & $\begin{array}{l}\text { (Benlian \& } \\
\text { Hess, 2011) }\end{array}$ & Germany & $\begin{array}{l}\text { Decision } \\
\text { Support Systems }\end{array}$ & ORF, TRA & $\mathrm{CC}$ & Survey & T01, T02 & & & & $\mathrm{R}$ \\
\hline 41 & $(\mathrm{Wu}, 2011 \mathrm{a})$ & Taiwan & $\begin{array}{l}\text { Expert } \\
\text { Systems with } \\
\text { Applications }\end{array}$ & TAM, DoI & $\mathrm{CC}$ & Survey & T01, T05 & $\mathrm{O} 05$ & E04 & $\begin{array}{l}\text { U01, } \\
\text { U02 }\end{array}$ & $\mathrm{R}$ \\
\hline 42 & $\begin{array}{l}\text { (Low et al., } \\
\text { 2011) }\end{array}$ & Taiwan & $\begin{array}{l}\text { Industrial } \\
\text { Management \& } \\
\text { Data Systems }\end{array}$ & TOE & $\mathrm{CC}$ & Survey & $\begin{array}{l}\text { T01, T04, } \\
\text { T06 }\end{array}$ & O03, O06, O09 & E01, E06 & & $\mathrm{R}$ \\
\hline 43 & (Sultan, 2011) & UK & $\begin{array}{l}\text { International } \\
\text { Journal of } \\
\text { Information } \\
\text { Management }\end{array}$ & - & $\mathrm{CC}$ & Case study & T01, T02 & & & & $\mathrm{D}$ \\
\hline 44 & (Wu, 2011b) & Taiwan & $\begin{array}{l}\text { The Journal } \\
\text { of Systems \& } \\
\text { Software }\end{array}$ & TAM & $\mathrm{CC}$ & Survey & T01, T05 & 005 & E04 & $\begin{array}{l}\text { U01, } \\
\text { U02 }\end{array}$ & $\mathrm{R}$ \\
\hline 45 & $\begin{array}{l}\text { (Aubert et al., } \\
\text { 2012) }\end{array}$ & Canada & $\begin{array}{l}\text { The Journal } \\
\text { of Strategic } \\
\text { Information } \\
\text { Systems }\end{array}$ & PCE, TCE & Ітомо & Survey & $\begin{array}{l}\text { T03, T04, } \\
\text { T07, T14 }\end{array}$ & $\mathrm{O} 01, \mathrm{O} 07$ & E03 & & $\mathrm{C}$ \\
\hline 46 & $\begin{array}{l}\text { (Garrison et al., } \\
\text { 2012) }\end{array}$ & $\begin{array}{l}\text { Multi- } \\
\text { national }\end{array}$ & $\begin{array}{l}\text { Communications } \\
\text { of the ACM }\end{array}$ & RBV & $\mathrm{CC}$ & Survey & T06 & $\mathrm{O} 02$ & & & $\mathrm{R}$ \\
\hline 47 & $\begin{array}{l}\text { (Martens \& } \\
\text { Teuteberg, } \\
\text { 2012) }\end{array}$ & Germany & $\begin{array}{l}\text { Information } \\
\text { Systems } \\
\text { Frontiers }\end{array}$ & - & $\mathrm{CC}$ & Case study & Т02, Т09 & & & & $\mathrm{R}$ \\
\hline 48 & $\begin{array}{l}\text { (Tajdini \& } \\
\text { Nazari, 2012) }\end{array}$ & Iran & $\begin{array}{l}\text { International } \\
\text { Journal of } \\
\text { Business and } \\
\text { Management }\end{array}$ & RBF & ISDO & Survey & T01, T02 & & & & $\mathrm{R}$ \\
\hline 49 & $\begin{array}{l}\text { (Messerschmidt } \\
\text { \& Hinz, 2013) }\end{array}$ & Germany & $\begin{array}{l}\text { The Journal } \\
\text { of Strategic } \\
\text { Information } \\
\text { Systems }\end{array}$ & $\begin{array}{l}\text { Institutional } \\
\text { theory, } \\
\text { OCT }\end{array}$ & $\mathrm{CC}$ & Survey & & $\begin{array}{l}\mathrm{O} 02, \mathrm{O} 03, \mathrm{O} 05 \\
\mathrm{O} 08, \mathrm{O} 12, \mathrm{O} 15, \\
\mathrm{O} 11\end{array}$ & E01, E06, E08 & & $\mathrm{R}$ \\
\hline 50 & $\begin{array}{l}\text { (Luo, Wang, } \\
\text { Jayaraman, \& } \\
\text { Zheng, 2013) }\end{array}$ & $\begin{array}{l}\text { China/ } \\
\text { India }\end{array}$ & $\begin{array}{l}\text { Journal of World } \\
\text { Business }\end{array}$ & TCE & $\begin{array}{l}\text { Offshore } \\
\text { outsourcing }\end{array}$ & Survey & $\begin{array}{l}\text { T05, T12, } \\
\text { T16 }\end{array}$ & $\mathrm{O} 03, \mathrm{O} 10$ & & & $\mathrm{C}$ \\
\hline 51 & $\begin{array}{l}\text { (Alshamaila et } \\
\text { al., 2013) }\end{array}$ & UK & $\begin{array}{l}\text { Journal of } \\
\text { Enterprise } \\
\text { Information } \\
\text { Management }\end{array}$ & TOE & $\mathrm{CC}$ & Case study & $\begin{array}{l}\text { T01, T03, } \\
\text { T04, T06, } \\
\text { T13 }\end{array}$ & $\begin{array}{l}\mathrm{O} 03, \mathrm{O} 04, \mathrm{O} 06 \\
\mathrm{O} 11, \mathrm{O} 25\end{array}$ & E01, E07, E12 & & $\mathrm{D}$ \\
\hline 52 & $\begin{array}{l}\text { (Y. Wu et al., } \\
\text { 2013) }\end{array}$ & USA & $\begin{array}{l}\text { Journal of } \\
\text { Supply Chain } \\
\text { Management }\end{array}$ & DoI & $\mathrm{CC}$ & Survey & T06, T16 & & & & $\mathrm{R}$ \\
\hline 53 & $\begin{array}{l}\text { (Lin \& Chen, } \\
\text { 2013) }\end{array}$ & Taiwan & $\begin{array}{l}\text { International } \\
\text { Journal of } \\
\text { Information } \\
\text { Management }\end{array}$ & TOE & $\mathrm{CC}$ & Survey & $\begin{array}{l}\text { T01, T04, } \\
\text { T13 }\end{array}$ & & & & $\mathrm{D}$ \\
\hline 54 & $\begin{array}{l}\text { (Brender \& } \\
\text { Markov, 2013) }\end{array}$ & Sweden & $\begin{array}{l}\text { International } \\
\text { Journal of } \\
\text { Information } \\
\text { Management }\end{array}$ & & $\mathrm{CC}$ & Case study & $\begin{array}{l}\text { T02, T05, } \\
\text { T09, T10 }\end{array}$ & $\mathrm{O} 03$ & E02 & & $\mathrm{D}$ \\
\hline 55 & $\begin{array}{l}\text { (Lee et al., } \\
\text { 2013) }\end{array}$ & $\begin{array}{l}\text { South } \\
\text { Korea }\end{array}$ & $\begin{array}{l}\text { International } \\
\text { Journal of } \\
\text { Information } \\
\text { Management }\end{array}$ & $\begin{array}{l}\text { Herzberg's } \\
\text { two-factor } \\
\text { theory }\end{array}$ & $\mathrm{CC}$ & Survey & $\begin{array}{l}\text { T01, T04, } \\
\text { T05, T10, } \\
\text { T12, T14 }\end{array}$ & O01, O16 & E02, E07 & & $\mathrm{D}$ \\
\hline 56 & $\begin{array}{l}\text { (Gupta, } \\
\text { Seetharaman, \& } \\
\text { Raj, 2013) }\end{array}$ & $\begin{array}{l}\text { Multi- } \\
\text { national }\end{array}$ & $\begin{array}{l}\text { International } \\
\text { Journal of } \\
\text { Information } \\
\text { Management }\end{array}$ & - & $\mathrm{CC}$ & Survey & $\begin{array}{l}\text { T01, T05, } \\
\text { T11 }\end{array}$ & & & U01 & $\mathrm{R}$ \\
\hline
\end{tabular}


Table 9. Continued

\begin{tabular}{|c|c|c|c|c|c|c|c|c|c|c|c|}
\hline Id & Citation & Context & Journal & $\begin{array}{l}\text { Base } \\
\text { Theory* }\end{array}$ & $\begin{array}{l}\text { Outsourcing } \\
\text { Strategy** }\end{array}$ & $\begin{array}{l}\text { Research } \\
\text { Method }\end{array}$ & $\begin{array}{l}\text { Technology } \\
\text { Factors }\end{array}$ & $\begin{array}{c}\text { Organizational } \\
\text { Factors }\end{array}$ & $\begin{array}{c}\text { Environmental } \\
\text { Factors }\end{array}$ & $\begin{array}{l}\text { User } \\
\text { Factors }\end{array}$ & Class**** \\
\hline 57 & $\begin{array}{l}\text { (Park \& Ryoo, } \\
\text { 2013) }\end{array}$ & $\begin{array}{l}\text { South } \\
\text { Korea }\end{array}$ & $\begin{array}{l}\text { Computers in } \\
\text { Human Behavior }\end{array}$ & $\begin{array}{l}\text { Two-factor } \\
\text { theory } \\
\text { (enablers/ } \\
\text { inhibitors) }\end{array}$ & $\mathrm{CC}$ & Survey & T01, T09 & & E04 & U03 & $\mathrm{R}$ \\
\hline 58 & $\begin{array}{l}\text { (Gooris \& } \\
\text { Peeters, 2014) }\end{array}$ & $\begin{array}{l}\text { Multi- } \\
\text { national }\end{array}$ & $\begin{array}{l}\text { Journal of } \\
\text { International } \\
\text { Management }\end{array}$ & TCE & $\begin{array}{l}\text { Offshore } \\
\text { outsourcing }\end{array}$ & Survey & & & E05, E10 & & $\mathrm{R}$ \\
\hline 59 & $\begin{array}{l}\text { (Wang \& He, } \\
\text { 2014) }\end{array}$ & Taiwan & $\begin{array}{l}\text { International } \\
\text { Journal of } \\
\text { Information } \\
\text { Management }\end{array}$ & - & $\mathrm{CC}$ & Case study & $\mathrm{T} 02$ & & & & $\mathrm{D}$ \\
\hline 60 & $\begin{array}{l}\text { (Lian et al., } \\
\text { 2014) }\end{array}$ & Taiwan & $\begin{array}{l}\text { International } \\
\text { Journal of } \\
\text { Information } \\
\text { Management }\end{array}$ & $\begin{array}{l}\text { TOE }+ \\
\text { HOT-fit }\end{array}$ & $\mathrm{CC}$ & Survey & $\begin{array}{l}\text { T01, T04, } \\
\text { T05, T06, } \\
\text { T09 }\end{array}$ & O01, O06, O11 & E01, E02 & & $\mathrm{C}$ \\
\hline 61 & $\begin{array}{l}\text { (Hsu et al., } \\
\text { 2014) }\end{array}$ & Taiwan & $\begin{array}{l}\text { International } \\
\text { Journal of } \\
\text { Information } \\
\text { Management }\end{array}$ & TOE & $\mathrm{CC}$ & Survey & T01, T02 & $\mathrm{O} 01, \mathrm{O} 03, \mathrm{O} 12$ & & & $\mathrm{R}$ \\
\hline 62 & $\begin{array}{l}\text { (Gerbl et al., } \\
\text { 2014) }\end{array}$ & Germany & $\begin{array}{l}\text { Journal of World } \\
\text { Business }\end{array}$ & TCE, RBV & $\mathrm{BPO}$ & Case study & $\begin{array}{l}\text { T02, T03, } \\
\text { T04, T08 }\end{array}$ & $\mathrm{O} 01$ & $\mathrm{E} 02, \mathrm{E} 10$ & & D \\
\hline 63 & (Ratten, 2014) & $\begin{array}{l}\text { USA/ } \\
\text { China }\end{array}$ & $\begin{array}{l}\text { Journal of } \\
\text { Entrepreneurship } \\
\text { in Emerging } \\
\text { Economies }\end{array}$ & TAM, SCT & $\mathrm{CC}$ & Survey & T01, T11 & & E04 & $\begin{array}{l}\text { U01, } \\
\text { U02, } \\
\text { U03 }\end{array}$ & $\mathrm{C}$ \\
\hline 64 & (Sultan, 2014) & UK & $\begin{array}{l}\text { International } \\
\text { Journal of } \\
\text { Information } \\
\text { Management }\end{array}$ & - & $\mathrm{CC}$ & Survey & T01 & & & & $\mathrm{D}$ \\
\hline 65 & $\begin{array}{l}\text { (Oliveira et al., } \\
\text { 2014) }\end{array}$ & Portugal & $\begin{array}{l}\text { Information \& } \\
\text { Management }\end{array}$ & DoI, TOE & $\mathrm{CC}$ & Survey & $\begin{array}{l}\text { T01, T04, } \\
\text { T05, T06 }\end{array}$ & O03, O06, O09 & E01, E02 & & $\mathrm{C}$ \\
\hline 66 & $\begin{array}{l}\text { (Yang, Sun, } \\
\text { Zhang, \& } \\
\text { Wang, 2015) }\end{array}$ & China & $\begin{array}{l}\text { Computers in } \\
\text { Human Behavior }\end{array}$ & TOE & $\mathrm{CC}$ & Survey & $\begin{array}{l}\text { T01, T06, } \\
\text { T13 }\end{array}$ & O06, O09 & E01, E06 & & $\mathrm{R}$ \\
\hline 67 & $\begin{array}{l}\text { (Rekik, } \\
\text { Boukadi, \& } \\
\text { Abdallah, } \\
2015 \text { ) }\end{array}$ & France & $\begin{array}{l}\text { International } \\
\text { Journal of Cloud } \\
\text { Computing }\end{array}$ & - & $\mathrm{CC}$ & Case study & T01, T09 & O07, O09 & & & D \\
\hline 68 & (Lu et al., 2015) & $\begin{array}{l}\text { Multi- } \\
\text { national }\end{array}$ & $\begin{array}{l}\text { Information } \\
\text { Systems } \\
\text { Frontiers }\end{array}$ & TCE, RBV & $\begin{array}{l}\text { Micro } \\
\text { sourcing }\end{array}$ & Survey & $\begin{array}{l}\text { T01, T02, } \\
\text { T03 }\end{array}$ & $\mathrm{O} 02$ & & & $\mathrm{R}$ \\
\hline 69 & $\begin{array}{l}\text { (Gerbl et al., } \\
2015 \text { ) }\end{array}$ & Germany & $\begin{array}{l}\text { Journal of World } \\
\text { Business }\end{array}$ & - & BPO & Case study & $\begin{array}{l}\text { T03, T04, } \\
\text { T08 }\end{array}$ & $\mathrm{O} 01, \mathrm{O} 10, \mathrm{O} 21$ & E02, E10, E16 & & D \\
\hline 70 & $\begin{array}{l}\text { (Atkinson, } \\
\text { Bayazit, \& } \\
\text { Karpak, 2015) }\end{array}$ & USA & $\begin{array}{l}\text { International } \\
\text { Journal of } \\
\text { Information } \\
\text { Systems and } \\
\text { Supply Chain } \\
\text { Management }\end{array}$ & - & Ітомо & Case study & $\begin{array}{l}\text { T02, T05, } \\
\text { T09, T11 }\end{array}$ & & & & D \\
\hline 71 & $\begin{array}{l}\text { (Safari et al., } \\
2015 \text { ) }\end{array}$ & Iran & $\begin{array}{l}\text { Journal of } \\
\text { Enterprise } \\
\text { Information } \\
\text { Management }\end{array}$ & TOE, DoI & $\mathrm{CC}$ & Survey & $\begin{array}{l}\text { T01, T03, } \\
\text { T04, T05, } \\
\text { T06, T11, } \\
\text { T13 }\end{array}$ & O09 & E01, E04 & & D \\
\hline 72 & $\begin{array}{l}\text { (Martins, } \\
\text { Oliveira, \& } \\
\text { Thomas, 2015) }\end{array}$ & $\begin{array}{l}\text { Multi- } \\
\text { national }\end{array}$ & $\begin{array}{l}\text { Journal of } \\
\text { Organizational } \\
\text { Computing } \\
\text { and Electronic } \\
\text { Commerce }\end{array}$ & TOE & ISDO & Survey & T01, T04 & O03, O06, O09 & $\mathrm{E} 01, \mathrm{E} 02$ & & $\mathrm{C}$ \\
\hline 73 & $\begin{array}{l}\text { (Gutierrez, } \\
\text { Boukrami, } \\
\text { \& Lumsden, } \\
2015 \text { ) }\end{array}$ & UK & $\begin{array}{l}\text { Journal of } \\
\text { Enterprise } \\
\text { Information } \\
\text { Management }\end{array}$ & TOE & $\mathrm{CC}$ & Survey & $\begin{array}{l}\text { T01, T04, } \\
\text { T06 }\end{array}$ & O03, O06, O09 & E01, E06 & & $\mathrm{R}$ \\
\hline 74 & $\begin{array}{l}\text { (Gerbl et al., } \\
\text { 2016) }\end{array}$ & Germany & $\begin{array}{l}\text { International } \\
\text { Journal of } \\
\text { Operations } \\
\text { \& Production } \\
\text { Management }\end{array}$ & TCE, RBV & BPO & Case study & $\begin{array}{l}\text { T03, T07, } \\
\text { T09 }\end{array}$ & & & & D \\
\hline
\end{tabular}


Table 9. Continued

\begin{tabular}{|c|c|c|c|c|c|c|c|c|c|c|c|}
\hline Id & Citation & Context & Journal & $\begin{array}{c}\text { Base } \\
\text { Theory* }\end{array}$ & $\begin{array}{l}\text { Outsourcing } \\
\text { Strategy** }\end{array}$ & $\begin{array}{l}\text { Research } \\
\text { Method }\end{array}$ & $\begin{array}{l}\text { Technology } \\
\text { Factors }\end{array}$ & $\begin{array}{c}\text { Organizational } \\
\text { Factors }\end{array}$ & $\begin{array}{c}\text { Environmental } \\
\text { Factors }\end{array}$ & $\begin{array}{l}\text { User } \\
\text { Factors }\end{array}$ & Class*** $^{* *}$ \\
\hline 75 & $\begin{array}{l}\text { (Bhatiasevi \& } \\
\text { Naglis, 2016) }\end{array}$ & Thailand & $\begin{array}{l}\text { Education and } \\
\text { Information } \\
\text { Technologies }\end{array}$ & TAM & $\mathrm{CC}$ & Survey & & & & $\begin{array}{l}\text { U01, } \\
\text { U02 }\end{array}$ & $\mathrm{R}$ \\
\hline 76 & $\begin{array}{l}\text { (Faisal \& Raza, } \\
\text { 2016) }\end{array}$ & $\begin{array}{l}\text { Multi- } \\
\text { national }\end{array}$ & $\begin{array}{l}\text { Journal of } \\
\text { Enterprise } \\
\text { Information } \\
\text { Management }\end{array}$ & - & Iтомо & Survey & T01 & & & & $\mathrm{D}$ \\
\hline 77 & $\begin{array}{l}\text { (Westphal \& } \\
\text { Sohal, 2016) }\end{array}$ & Australia & $\begin{array}{l}\text { Production } \\
\text { Planning and } \\
\text { Control }\end{array}$ & - & IтOMO & Case study & & $\begin{array}{l}\text { O04, O06, O10, } \\
\text { O14 }\end{array}$ & & & $\mathrm{D}$ \\
\hline 78 & $\begin{array}{l}\text { (Wu, Ding, } \\
\text { Xu, Mo, \& Jin, } \\
\text { 2016) }\end{array}$ & China & $\begin{array}{l}\text { Journal } \\
\text { of Global } \\
\text { Information } \\
\text { Management }\end{array}$ & - & $\mathrm{CC}$ & Survey & $\begin{array}{l}\text { T02, T05, } \\
\text { T06, T09 }\end{array}$ & & & & $\mathrm{R}$ \\
\hline 79 & $\begin{array}{l}\text { (Alharbi, } \\
\text { Atkins, \& } \\
\text { Stanier, 2016) }\end{array}$ & $\begin{array}{l}\text { Saudi } \\
\text { Arabia }\end{array}$ & $\begin{array}{l}\text { Complex \& } \\
\text { Intelligent } \\
\text { Systems }\end{array}$ & TOE & $\mathrm{CC}$ & Survey & T01, T06 & $\begin{array}{l}\text { O01, O04, O05, } \\
\text { O06, O09, O17 }\end{array}$ & E06 & & $\mathrm{C}$ \\
\hline 80 & $\begin{array}{l}\text { (van de Weerd, } \\
\text { Mangula, \& } \\
\text { Brinkkemper, } \\
\text { 2016) }\end{array}$ & Indonesia & $\begin{array}{l}\text { Information \& } \\
\text { Management }\end{array}$ & - & $\mathrm{CC}$ & Case study & & $\begin{array}{l}\text { O01, O03, O06, } \\
\text { O09 }\end{array}$ & & & $\mathrm{D}$ \\
\hline 81 & $\begin{array}{l}\text { (Karunagaran et } \\
\text { al., 2017) }\end{array}$ & Germany & $\begin{array}{l}\text { Information } \\
\text { Systems } \\
\text { Frontiers }\end{array}$ & TOE & $\mathrm{CC}$ & Case study & $\begin{array}{l}\text { T01, T02, } \\
\text { T03, T04, } \\
\text { T05, T09, } \\
\text { T10, T12, } \\
\text { T13, T14 }\end{array}$ & $\mathrm{O} 16, \mathrm{O} 22$ & E01, E03, E13 & & $\mathrm{C}$ \\
\hline 82 & $\begin{array}{l}\text { (Alassafi, } \\
\text { Alharthi, } \\
\text { Walters, \& } \\
\text { Wills, 2017) }\end{array}$ & $\begin{array}{l}\text { Saudi } \\
\text { Arabia }\end{array}$ & $\begin{array}{l}\text { Telematics and } \\
\text { Informatics }\end{array}$ & - & $\mathrm{CC}$ & Case study & $\begin{array}{l}\text { T02, T05, } \\
\text { T06, T10, } \\
\text { T12 }\end{array}$ & $\mathrm{O} 02$ & & & $\mathrm{D}$ \\
\hline 83 & $\begin{array}{l}\text { (Loukis, } \\
\text { Arvanitis, \& } \\
\text { Kyriakou, } \\
\text { 2017) }\end{array}$ & $\begin{array}{l}\text { Multi- } \\
\text { national }\end{array}$ & $\begin{array}{l}\text { Information } \\
\text { Systems and } \\
\text { e-Business } \\
\text { Management }\end{array}$ & TOE & $\mathrm{CC}$ & Survey & & $\begin{array}{l}\mathrm{O} 01, \mathrm{O} 03, \mathrm{O} 04 \\
\mathrm{O} 05, \mathrm{O} 11\end{array}$ & E01 & & $\mathrm{R}$ \\
\hline 84 & $\begin{array}{l}\text { (Raut, Gardas, } \\
\text { Jha, \& } \\
\text { Priyadarshinee, } \\
\text { 2017) }\end{array}$ & India & $\begin{array}{l}\text { Journal of High } \\
\text { Technology } \\
\text { Management } \\
\text { Research }\end{array}$ & - & $\mathrm{CC}$ & Survey & $\begin{array}{l}\text { T01, T05, } \\
\text { T06, T11, } \\
\text { T13 }\end{array}$ & $\begin{array}{l}\mathrm{O} 01, \mathrm{O} 03, \mathrm{O} 04 \\
\mathrm{O} 06, \mathrm{O} 11, \mathrm{O} 12\end{array}$ & E01, E02, E03 & U01 & $\mathrm{R}$ \\
\hline 85 & $\begin{array}{l}\text { (Williams \& } \\
\text { Durst, 2018) }\end{array}$ & UK & $\begin{array}{l}\text { Journal of } \\
\text { Business } \\
\text { Research }\end{array}$ & - & $\begin{array}{l}\text { Offshore } \\
\text { outsourcing }\end{array}$ & Case study & & & $\mathrm{O} 21$ & & $\mathrm{D}$ \\
\hline 86 & $\begin{array}{l}\text { (Mukherjee, } \\
\text { 2018) }\end{array}$ & India & $\begin{array}{l}\text { Journal of } \\
\text { Industry, } \\
\text { Competition and } \\
\text { Trade }\end{array}$ & - & $\begin{array}{l}\text { Offshore } \\
\text { outsourcing }\end{array}$ & Case study & T09 & & & & $\mathrm{C}$ \\
\hline 87 & $\begin{array}{l}\text { (Raut et al., } \\
\text { 2018) }\end{array}$ & India & $\begin{array}{l}\text { Technological } \\
\text { Forecasting and } \\
\text { Social Change }\end{array}$ & - & $\mathrm{CC}$ & Survey & T02 & $\mathrm{O} 02, \mathrm{O} 22$ & & & $\mathrm{R}$ \\
\hline 88 & $\begin{array}{l}\text { (Kauffman et } \\
\text { al., 2018) }\end{array}$ & $\begin{array}{l}\text { Multi- } \\
\text { national }\end{array}$ & $\begin{array}{l}\text { Electronic } \\
\text { Markets }\end{array}$ & TOE & $\mathrm{CC}$ & Case study & $\begin{array}{l}\text { T01, T05, } \\
\text { T06 T09 }\end{array}$ & $\mathrm{O} 11, \mathrm{O} 23$ & $\begin{array}{l}\text { E01, E02, E03, } \\
\text { E06 }\end{array}$ & & $\mathrm{D}$ \\
\hline 89 & $\begin{array}{l}\text { (Zhang, Liu, } \\
\text { Tan, Jiang, \& } \\
\text { Zhu, 2018) }\end{array}$ & China & $\begin{array}{l}\text { International } \\
\text { Journal } \\
\text { of Project } \\
\text { Management }\end{array}$ & - & $\mathrm{BPO}$ & Survey & T02 & & & & $\mathrm{R}$ \\
\hline 90 & $\begin{array}{l}\text { (Alkhater, } \\
\text { Walters, \& } \\
\text { Wills, 2018) }\end{array}$ & $\begin{array}{l}\text { Saudi } \\
\text { Arabia }\end{array}$ & $\begin{array}{l}\text { Telematics and } \\
\text { Informatics }\end{array}$ & TOE & $\mathrm{CC}$ & Survey & $\begin{array}{l}\text { T01, T05, } \\
\text { T06, T11, } \\
\text { T13 }\end{array}$ & $\begin{array}{l}\mathrm{O} 02, \mathrm{O} 06, \mathrm{O} 09, \\
\mathrm{O} 25\end{array}$ & $\begin{array}{l}\text { E01, E02, E04, } \\
\text { E10 }\end{array}$ & & $\mathrm{C}$ \\
\hline 91 & $\begin{array}{l}\text { (Hanafizadeh \& } \\
\text { Zare Ravasan, } \\
\text { 2018a) }\end{array}$ & Iran & $\begin{array}{l}\text { Journal } \\
\text { of Global } \\
\text { Information } \\
\text { Technology } \\
\text { Management }\end{array}$ & TOE & Ітомо & Survey & $\begin{array}{l}\text { T01, T02, } \\
\text { T03, T04, } \\
\text { T07, T08, } \\
\text { T09, T15 }\end{array}$ & $\begin{array}{l}\mathrm{O} 02, \mathrm{O} 03, \mathrm{O} 04 \\
\mathrm{O} 06, \mathrm{O} 09, \mathrm{O} 10 \\
\mathrm{O} 21, \mathrm{O} 23, \mathrm{O} 24\end{array}$ & $\begin{array}{l}\text { E01, E03, E05, } \\
\text { E07, E15 }\end{array}$ & & $\mathrm{R}$ \\
\hline
\end{tabular}

* TCE: Transaction Cost Economics, RBV: Resource-Based View, RDT: Resource dependence theory, KBP: Knowledge-based perspective: TOE: Technology-Organization-Environment; TAM: Technology Acceptance Model; TPB: Theory of Planned Behavior; TRA: Theory of Reasoned Action; SMT: Strategic Management Theory; Dol: Diffusion of Innovation theory; HOT-fit: Human-Organization-Technology fit; RBF: Risk -benefits framework; PCE: Production costs economics; RET: Relational Exchange Theory; CSR: Corporate Social Responsibility; ORF: Opportunity Risk framework; SCT: Social Cognitive Theory; OCT: Organizational Capability Theory

${ }^{* *}$ ISDO: IS development outsourcing; ITOMO: IT operations and maintenance outsourcing; CC: Cloud Computing; BPO: Business Process Outsourcing

${ }^{* * \star} \mathrm{D}$ : Descriptive, R: Relational, C: Comparative 
Payam Hanafizadeh has held visiting positions at the University of Waterloo, University of Canberra, Chalmers University of Tech., Masaryk University and Universidad Autónoma de Madrid. He received his MSc and PhD in Industrial Engineering at Tehran Polytechnic University and pursues his research in the areas of e-business and decision making under uncertainty. He was the former Editor-in-Chief of International Journal of E-Business Research. He is the inventor of Robust Net Present Value appeared in Mathematical and Computer Modelling. He has also published over 60 articles for leading journals such as: Internet Research, The Information Society, Journal of Global Information Management, Telecommunications Policy, Expert Systems with Applications, International Journal of Information Management, Systemic Practice and Action Research, Electronic Commerce Research, Mathematical and Computer Modelling, Energy Policy, Management Decisions and Telematics and Informatics to name only a few. Dr. Hanafizadeh is the co-author of Online Advertising and Promotion published by IGI Global. He has (co-)authored several other successful books in Persian such as Electronic Commerce, Definitions and Barriers (2nd edition), Holding Companies: Definitions, Concepts, and Structures, and Multi-Dimensional Construct Research Method. He has also been serving on the Editorial Review Board for JITR, JECO, IJITSA, IJEIS, and IJDSST. Dr. Hanafizadeh was named as the best researcher of Tehran Province in 2006. In addition to his academic position, he has also consulted for several major public and private organizations including the Ministry of Information, Telecommunication and Technology, the Ministry of Interior, National Petrochemical Company, pharmaceutical companies, automotive companies, and banking industries.

Ahad Zareravasan is a Post-Doctoral researcher at Masaryk University, Brno, Czech Republic. He has published over 30 papers in acclaimed journals, such as the International Journal of Information Management, Expert Systems with Applications, Information Systems, International Journal of Production Research, Journal of Enterprise Information Management, Production Planning \& Control, and Telecommunication Systems. His research interests include Big Data Analytics, business process outsourcing and Blockchain. 